\title{
Measurement and implications of marine food security in the Western Indian Ocean: an impending crisis?
}

\author{
Sarah F. W. Taylor ${ }^{1,2}$ (D) Michael J. Roberts ${ }^{1,3} \cdot$ Ben Milligan $^{4} \cdot$ Ronney Ncwadi ${ }^{2}$
}

Received: 29 March 2019 / Accepted: 24 August 2019/Published online: 18 October 2019

(C) The Author(s) 2019

\begin{abstract}
Ten percent of the world's population depends on the ocean for a readily accessible source of protein and employment. Coastal ecosystems and the communities that rely upon them are facing extreme challenges of increases in ocean pollution, loss of habitat, ocean warming, and changes in ocean productivity. With the whole system under mounting pressure, governments need to scale down food security analyses to the coastal community level to avoid overseeing rising levels of food insecurity. This paper provides an alternative view and analysis of food security at both a national and community level taking into account these marginalised communities. The results propose a refined definition of marine food security and new quantitative methods to measuring direct and indirect reliance on fish within developing countries. Application of this concept and methods reveals that aggregated national statistics mask the extreme levels of dependence on fish for food security in coastal communities within Kenya and Madagascar. The Comoros, Mauritius, Mozambique, and Somalia appear to be the most vulnerable to increasing sea surface temperature, population, and fluctuation in total catch and will be severely affected by a changing Western Indian Ocean from a national, community, and individual perspective. Overall, the study highlights that governments need to disaggregate fisheries data and redefine measurements of food security to more accurately reveal the severity of the potential marine food insecurity crisis at hand.
\end{abstract}

Keywords Food security $\cdot$ Fish $\cdot$ Small-scale fisheries $\cdot$ Fisheries $\cdot$ Coastal communities $\cdot$ Ocean productivity

\section{Introduction}

The number of people worldwide suffering from hunger increased from around 804 million in 2016 to almost 821 million in 2017 (FAO 2018a). Climate variability and extremes are notably a key driver behind the rise in global hunger. Climate change, as one of the leading causes of severe food crises, negatively influences all aspects of food security including food availability, access, utilisation, and stability. Ten percent of the global population depends on the ocean

Sarah F. W. Taylor

sarah.taylor@noc.ac.uk

1 National Oceanography Centre, European Way, Southampton SO14 3ZH, UK

2 Nelson Mandela University, Port Elizabeth, South Africa

3 Ocean Sciences, Nelson Mandela University, Port Elizabeth, South Africa

4 University of New South Wales, Sydney, Australia for an accessible source of protein and employment with the majority (95\%) living in developing countries (FAO 2014). Climate change is effecting coastal and marine ecosystems and consequently influencing fisheries and communities reliant on these ecosystems. Simultaneously, demand for fish keeps growing at a rapid rate with per capita annual consumption of fish doubling since the 1960s (Blasiak et al. 2017). Coastal communities and fisheries in developing countries are at the frontier for climate change impacts, compounded by population growth and food demand, but are among the least resilient to the challenges of the future.

The case of the Western Indian Ocean (WIO) is becoming the quintessential scenario of coastal communities and developing economies experiencing the aftereffects of climate change influencing a major source of food and livelihoods the ocean. Of particular interest are those Least Developed Countries and island states on the eastern side of Africa, namely the Comoros, Kenya, Madagascar, Mozambique, and Tanzania. Together with Mauritius and Seychelles (both upper middle income), this block is commonly referred to as the WIO countries (Fig. 1; oecd.org). They have a total 


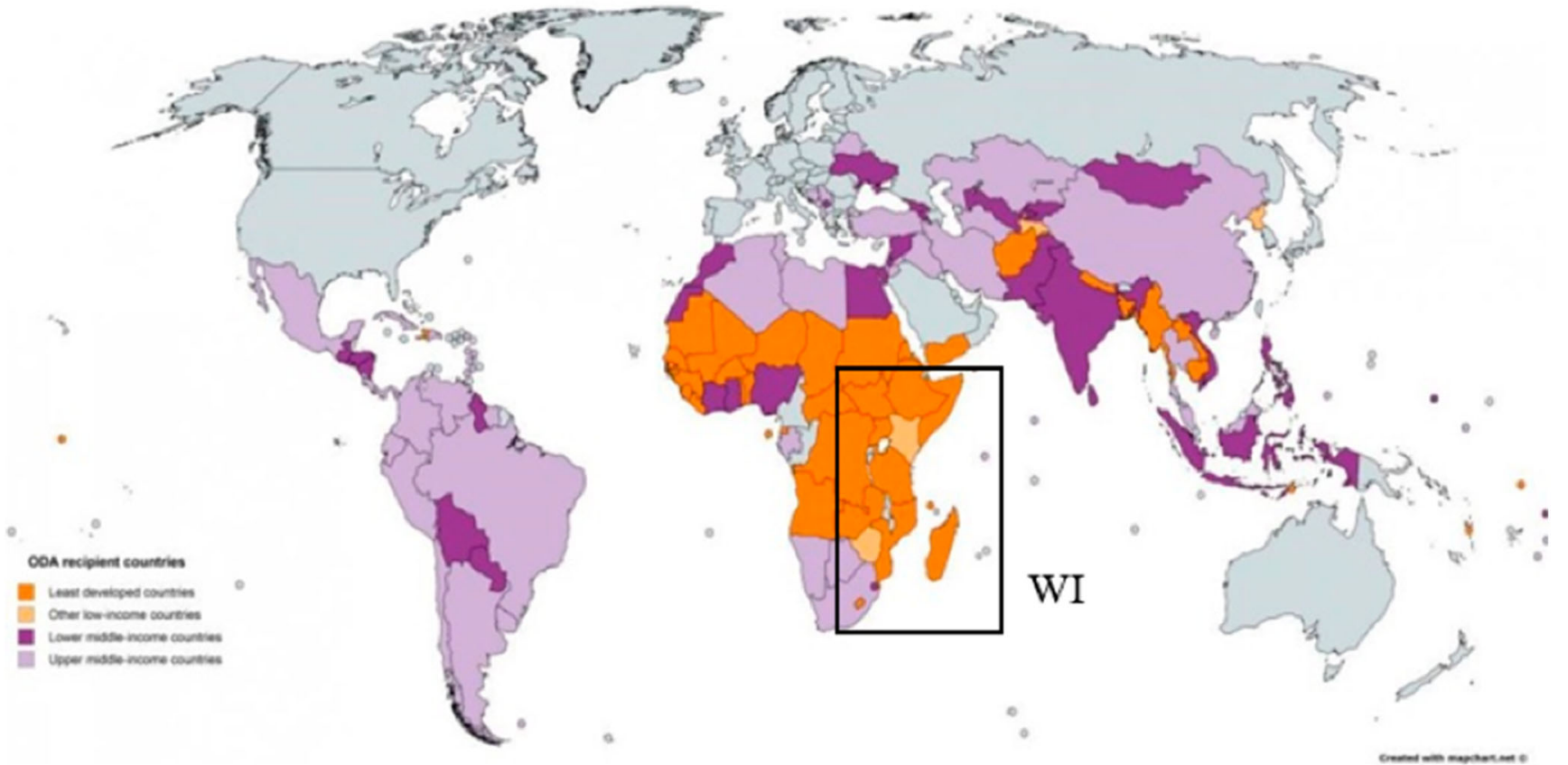

Fig. 1 Map showing ODA recipient countries and their level of development (source: oecd.org). The block box highlights the Western Indian Ocean countries

population of over 135 million with the proportion of population in the coastal zone varying in country but particularly high on the islands. Estimates suggest that 30 60 million people in the WIO coastal communities are dependent on the coastal environment for goods, services, livelihood and income (UNEP-Nairobi Convention and WIOMSA 2015). The only other similar situations of highly dense ocean-dependent coastal communities worldwide are the Bay of Bengal and the west coast of Africa. In all cases, subsistence and artisanal fisheries are paramount to their fishing industries and coastal communities by providing direct and indirect food security to the coastal population (Fig. 2).

The growing concern for the WIO is that observations and models show this region of the ocean to be undergoing some of the fastest changes seen globally. In 1990, the Intergovernmental Panel on Climate Change (IPCC) released its first scientific assessment of climate change research (Houghton et al. 1990) and concluded then that a warming of about $0.38{ }^{\circ} \mathrm{C}$ had occurred over the last century in the Northern Hemisphere oceans, and about $0.38-0.58{ }^{\circ} \mathrm{C}$ in the Southern Hemisphere (Folland et al. 1990). This was not good news for the coastal and marine ecosystems of the WIO countries, as coral reefs are highly exposed to bleaching, mangroves are exposed to sedimentation and sea level rise, and coastal lands to flooding and erosion (UNEP-Nairobi Convention and WIOMSA 2015). Community livelihoods have the same vulnerability scale particularly coastal agriculture, fisheries, human health and industrial activities. Added to this was a study by Roxy et al. (2014) who suggested the WIO has not only been warming for more than a century, but at a rate faster than any other region of the tropical oceans, and appears to be the largest contributor to the overall trend in the global mean sea surface temperature (SST) (further detail given in Fig. 6). During the period 1901-2012, while the Indian Ocean warm pool went through an increase of $0.78{ }^{\circ} \mathrm{C}$, the WIO experienced anomalous warming of $1.28^{\circ} \mathrm{C}$ in summer
Fig. 2 Villagers in Zanzibar eagerly await their fishermen (source: Patrick Kimani)

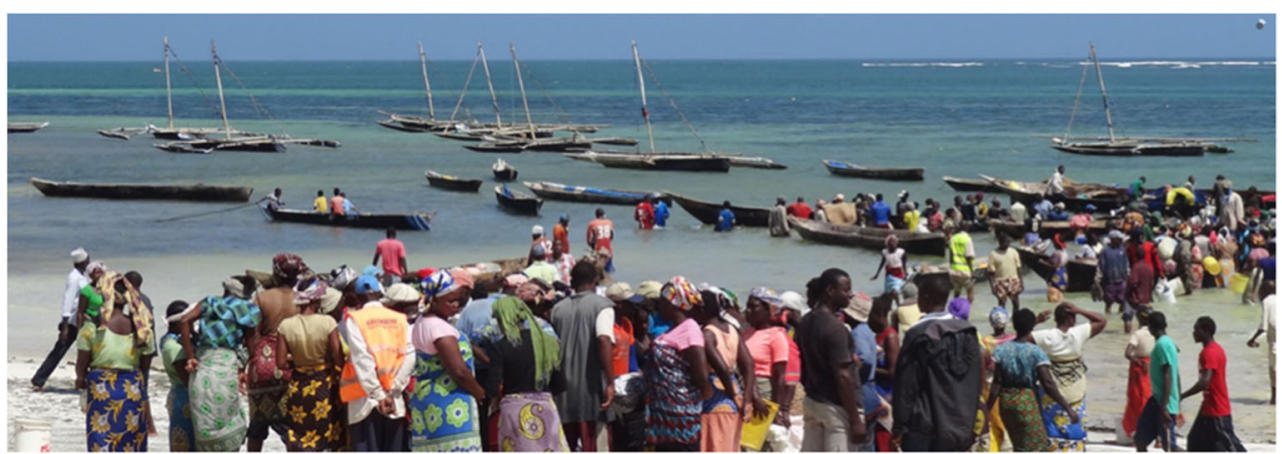


SSTs. The warming of the generally cool WIO against the rest of the tropical warm pool region alters the zonal SST gradients, and has the potential to change the Asian monsoon circulation and rainfall, as well as alter marine food webs in this biologically productive region.

The WIO hosts one of the largest summer concentrations of marine phytoplankton blooms in the world's tropical oceans. Another study by Roxy et al. (2015) points out an alarming decrease of up to $20 \%$ in phytoplankton in this region over the past six decades. This is driven by enhanced ocean stratification due to rapid warming in the Indian Ocean, which suppresses nutrient mixing from subsurface layers. The authors concluded that future climate projections suggest that the Indian Ocean will continue to warm, driving this productive region into an ecological desert.

Evidence of global warming continues to grow as researchers from NOAA in 2017 (Huanga et al. 2017) updated their reconstructed observational global SST time series and concluded that the oceans have actually warmed $0.12{ }^{\circ} \mathrm{C}$ per decade since 2000 - nearly twice as fast as earlier estimates of $0.07^{\circ} \mathrm{C}$ per decade, corroborating the IPCC Fifth Assessment Report (2013) which showed that leading climate change models predicted a much faster increase in ocean heat content over the last 30 years than observations. In a brand new article, Cheng et al. (2019) "How fast are the oceans warming?" demonstrates that ocean warming continues to accelerate.

Assuming a "business-as-usual" scenario in which no effort has been made to reduce greenhouse gas emissions, the Coupled Model Intercomparison Project 5 (CMIP5) models predict that the temperature of the top $2000 \mathrm{~m}$ of the world's oceans will rise $0.78{ }^{\circ} \mathrm{C}$ by the end of the century. The resulting thermal expansion will raise sea levels $30 \mathrm{~cm}$ on top of the already significant sea level rise caused by melting glaciers and ice sheets. Warmer oceans also contribute to stronger storms, hurricanes and extreme precipitation. For the WIO it is anticipated that precipitation will be less abundant during dry seasons and more intense during rainy seasons, and the average rainfall will be higher for the Comoros, Kenya, Seychelles, Tanzania, and reduced for Madagascar, Mozambique and Mauritius (Rakotobe 2012). The increased frequency of intense cyclones registered in recent years will continue.

In addition to the countries of the WIO experiencing changes in ocean productivity, there is growing concern in the Indian Ocean Tuna Commission (IOTC) of increased fishing capacity in high seas by distant fishing fleets impacting coastal states. At a time where future access to overfished key tropical species and access arrangements with distant water fishing nations, coastal states need to understand their dependence on fish for both local consumption and economic benefits from trade. Such issues may result in limited access to marine food resources for coastal states (Teh et al. 2016), as well as revenue generated from access arrangements potentially not being directed back into maintaining impacted levels of food security in coastal communities. This pertinent issue highlights the need for disaggregated and scaled-down food security analyses. Revenue from access arrangements may be viewed as economic growth which is often assumed to benefit food security and access from a national perspective (Ravallion and Chen 1997; Roemer and Gugerty 1997). However, when addressing the impact of restricted access to marine resources from a coastal community perspective, the trade-off may not be worthwhile.

Given the high dependence of WIO coastal communities on the marine environment, particularly for their diet, and the rapid adverse changes occurring in the Indian Ocean and its ecosystems - there is a clear need to accurately assess the status of food security - particularly in the LCDs. From a food security perspective, key issues facing countries of the WIO are: (i) reduced ocean productivity influencing and changing marine productivity patterns in food-sensitive regions; (ii) a growing population increasing the demand for seafood; (iii) a high level of dependence on fisheries for fish as food and livelihoods; (iv) a high dependence of developing countries on small-scale fisheries for economic growth. Both (iii) and (iv) of are high importance as both issues are often masked and overseen within national food security analyses.

To address this in a definitive and quantitative manner, we need to know (1) how many people are really involved in the fisheries and live in the coastal communities of the WIO, (2) their spatial distribution, (3) the extent to which they are dependent on the ocean for food, and (4) anticipated changes in ocean productivity including non-linear "tipping points."

This paper focuses around the pivotal point of (3) above. It first revisits the formal definitions of food security and recognises that coastal communities are often masked or overlooked in these aggregated global and national scales of food security. We suggest a new approach to food security, namely marine food security, which refines the concept to specifically assessing levels of dependence on the ocean for securing levels of food security. The definition of marine food security is based on the global definition of food security but utilises both a national and community based perspective of food security to create refined methods of quantifying the levels of dependence on marine assets for economic growth and as a food source.

Do national definitions and measurements of food security accurately reflect scaled-down scenarios such as the potential looming coastal community food insecurity? The gravity of the paper deals with this question by proposing a more granular measurement framework and testing it for the WIO region based on global and local datasets. The marine food security definition and framework developed (illustrated in Fig. 5) demonstrates the direct and indirect aspects of how developing countries are dependent on fish for national economic growth and as a food source on an individual and community level. We quantify the dependence of the developing 
economies on small-scale fisheries and how dependent coastal communities are on fish. This case study on countries of the WIO aims to emphasise the urgency of disaggregating national fisheries data and concepts of food security to prevent assumptions of homogeneity masking potential impending food insecurity crises. A key question is how severe is the problem?

\section{Methods}

The methods used to address the key issues facing the WIO from a food security perspective involve: a qualitative analysis of the traditional concept of food security; an empirical analysis of traditional methods to measuring national food security; an analysis of national dependence on fish; and then finally we propose a refined concept - marine food security - as a means to better include marginalised marine-dependent coastal communities. New methods of quantifying marine food security are proposed and tested for countries of the WIO on both a national and community-based scale. The countries analysed are the Comoros, Kenya, Madagascar, Mauritius, Seychelles, Somalia, South Africa, and Tanzania.

It should be noted that subsistence fisheries are defined as a fishery where the fish caught are shared and consumed directly by the families and kin of the fishers rather than being bought by middle-(wo)men and sold at the next larger market (FAO 1999a). Artisanal fisheries are traditional fisheries involving fishing households using a relatively small amount of capital and energy, relatively small fishing vessels if any, making short fishing trips that are close to shore mainly for the purpose of local consumption (FAO 1999a). Artisanal fisheries can be subsistence or commercial fisheries providing for consumption or export.

Small-scale fisheries are a dynamic and evolving subsector of fisheries employing labour-intensive harvesting, processing, and distribution technologies to exploit fishery resources (FAO 2004). This sub-sector is not homogenous within countries as these fisheries operate at differing organisational levels ranging from self-employed single operators to informal sector businesses serving both local markets and international markets.

Coastal communities are defined within this paper as coastal settlements within a local authority area whose boundaries include the foreshore, including local authorities whose boundaries only include estuarine foreshore (Coastal Communities Alliance 2015).

\section{Analysing the traditional concept of food security}

The concept and relative studies on food security have developed from being mostly concerned with national and global food supplies in the 1970s (FAO 1979; Guerrero 2010), to a more inclusive understanding incorporating households and individuals in the definition (FAO 1983; Brink 2001; Applanaidu et al. 2014). The Food and Agriculture Organisation (FAO) defines food security as "when all people, at all times, have physical, social, and economic access to sufficient, safe, and nutritious food that meets their dietary needs and food preferences for an active and healthy life" (FAO 2011). This definition implies the Four Pillars Model, which addresses food availability, food access, the utilisation of food, and the stability of food sources (FAO 2008). By emphasising all people at all times the FAO definition depicts a global perspective of food security. Other definitions have attempted to more accurately address issues such as equality and equity such as Powledge (2012) including equal and consistent access to food by all people.

The level of food security addressed influences the practical application of the concept. Over the years food security policies and programmes have been based on global, national, regional, community, household, or individual scales. The most common food security assessments are done at the global or national scale. Although community perspectives of food security are highly relevant and important as they have the potential to change the way food security studies are done at all levels, they are the least common due to cost and specificity (Cochrane 2017). These smaller scale assessments effectively emphasise the specific dynamics of complex food systems, which allows a deeper understanding of how food security issues should be solved at this level.

The food security concept, and subsequent solutions, therefore should not assume homogeneity within multiple communities whereby food sources hold different social and cultural importance (Uraguchi et al. 2018). The importance of emphasising the distinct aspects and variables of different food economies will allow the study to not limit the understanding of food security to a problem only of supply. New problems such as resource exhaustion, climate change, and unsustainable development policies have added to a more holistic understanding of the food security problem and should be addressed (Funk et al. 2008; Garcia et al. 2010; Rice and Garicia 2011).

Although total capture production of all fisheries in the WIO supported a total catch of 4.9 million tons of fish in 2016 (FAO 2016a) with fisheries and aquaculture generating around US\$1.9billion annually (Obura et al. 2017), most fishers in the region are among the poorest in society and levels of hunger are still alarming. This paradox exemplifies how food security on a national scale does not necessarily imply that food security exists on an individual level (Broca 2002). Effectively breaking apart challenging case studies, like the case of food security in the WIO, should involve a mixedmethods approach such as Cochrane's (2017) Stages of Food Security methodology employed to assess food security 
in Ethiopia. These mixed-method approaches draw upon qualitative and quantitative processes to speak the 'language' of decision makers. What do countries experiencing potential food insecurity need to address and measure?

Complex food system and economy needs to be understood and measured at both a national and community level. A national perspective of food security focuses on domestic food self-sufficiency. Food self-sufficiency is achieved when a country can successfully produce enough food to meet domestic demand (Clapp 2017). Assessments of food security on a national scale often focus on measuring and analysing aggregate demands and availability. There is danger in only addressing this perspective as the aggregation can mask smaller scale food insecurity. The case of South Africa illustrates this as the country is food secure on a national level; however, a study done on food security in South Africa (De Cock et al. 2013) scaled down the problem and conducted 599 household assessments revealing that $53 \%$ of the sampled rural households in Limpopo were severely food insecure.

Understanding isolated groups such as small-scale fishing communities exposes the complexity of food systems and different levels of food security. The assumption that food availability guarantees access does not hold true in all communities. Access encompasses having physical, social, and economic access to food so to enable sufficient "entitlement to food" (Sen 1982). Subsistence fishers in isolated fishing communities that directly rely on fish as a source of food (Béné et al. 2007) may not have the geographic access to or the financial ability to access other food types. In theory they are financially excluded from domestic markets selling the food produce that has been imported to sustain a national level of food security. In a scenario where fish stocks are depleted what would this mean for these marginalised groups?

A critical aspect of food security to clarify is the difference between food as subsistence and food as a commodity contributing to food security as an economic activity (Béné 2006). Producing food through fishing activities can contribute directly to individual food security, referring to the subsistence element of the activity as fishers then have direct access to a supply of food (Thompson et al. 2002; Bell et al. 2009; Singh 2009). This may also contribute indirectly to the individual's food security through incomes such as selling portions of catch or receiving an income from a formal fishery sector, allowing the individual to buy food (Allison 2005; Smith et al. 2005; Heck et al. 2007).

The price of food affects the status of food security in vulnerable countries and economies (Gustafson 2013; van Wyk and Dlamini 2018). In coastal communities fishers that have access to markets and are willing to participate in the markets sell and/or buy fish and other food types. The influence of food prices becomes evident in this scenario as food access and availability are linked by the price of food within these markets. Food availability represents the supply side of the food security equation and access to food represents the effective demand. Food prices link the two sides of the equation (Timmer et al. 1983). It has been reported that by 2050 , millions of people in developing countries might not be able to afford fish, which currently is relied on as a major source of food and protein (WWF 2016) thereby potentially disabling sufficient access to a critical food source.

The dimension of food stability is similarly important for coastal communities. A decrease in the productivity of the WIO will impact spawning and recruitment processes of fish stocks. The change in fish distributions may impact the stability of species that are relied on as one of the coastal communities' major food sources or most valued species in domestic and international markets. Food stability implies that people must have access to adequate food at all times (FAO 2006). The case for vulnerable small-scale fisheries needs to be made because fishers directly dependent on catch for food security sometimes without alternatives, such as income to purchase food, will be hit the hardest by fluctuations in access to fish as food. Fishers in isolated areas may not have access to redistribution mechanisms emphasising the need to progress discourse around individual food entitlement (Béné 2006). The heart of food insecurity problems often lies at the misunderstanding that all individuals have equal access to the adequate food supply at a national-self sufficiency level.

\section{Global and National Measurements of food security}

\subsection{Prevalence of food insecurity}

The 2018 State of Food Security and Nutrition in the World report revealed increasing levels of global hunger with almost all sub-regions of Africa experiencing increasing undernourishment and severe food insecurity (FAO 2018a). The FAO report (2018a) measures food insecurity levels based on results of the Food Insecurity Experience Scale (FIES) survey module. This is the first method that has been used to measure food insecurity at the individual level globally (Wambogo et al. 2018). The method allows for results to be disaggregated, making it valuable in the process of identifying subpopulations mostly affected by food insecurity (FAO 2018a).

The FIES methodology is now a global measurement standard of food insecurity. This indicator defines food insecurity by limited access to food at the individual or household level. The eight-question FIES survey module is generally applied to nationally representative samples of around 1000 individuals in most countries.

A scale of food-insecurity is constructed using the Rasch model, which hypothesises that the probability of respondent $i$ responding affirmatively to question $j$ is a logistic function of 
the distance, on an underlying scale of severity, between the position of the respondent, $a_{i}$, and that of the item, $b_{j}$.

$\operatorname{Prob}\left(X_{i, j}=\right.$ Yes $)=\frac{\exp \left(a_{i}-b_{j}\right)}{1+\exp \left(a_{i}-b_{j}\right)}$

Applying the Rasch model to the FIES data results in an estimate of the probability of being food insecure $\left(p_{i, L}\right)$ at any given level of severity of food insecurity $L$, for each respondent $i$, with $0<p_{i, L}<1$.

The prevalence of food insecurity at a given level of severity $\left(F I_{L}\right)$ in the population is calculated as the weighted sum of the probability of being severely food insecure for all respondents $(i)$ in a sample:

$F I_{L}=\sum p_{i, L} w_{i}$

where $w_{i}$ are post-stratification weights indicating the proportion of individuals or households in the national population represented by each record in the sample. Samples are only taken from the adult population, which is defined as aged 15 or older.

Regional and global aggregates of food insecurity at severe levels, $F I_{L}$, are calculated as:

$F I_{L, r}=\frac{\sum_{c} F I_{L, c} \times N_{c}}{\sum_{c} N_{c}}$

where $r$ specifies the region, $F I_{L, c}$ is the value of $F I$ at level $L$ estimated for country $c$ in the region and $N_{c}$ is the corresponding population size.

\subsection{Prevalence of undernourishment}

The Prevalence of Undernourishment (PoU) is the FAO indicator used to assess and measure hunger at both global and national levels by addressing levels of undernourishment. The PoU estimates the percentage of individuals in the total population that are in the condition of undernourishment. The household surveys used to collect data for this indicator do not provide direct evidence on individual food consumption (FAO 2018a). The distribution of consumption is modeled for the population's representative individual, therefore limiting the results made on assumptions of the representatives in which the data were collected from.

\subsection{National food self-sufficiency}

National food self-sufficiency is defined by the FAO (1999b) as the extent to which a country can meet its food supply needs from domestic production. One of the traditional measurements of food self-sufficiency is assessing the net food trade position of a country. National food selfsufficiency can be measured by determining if a country is a net exporter of basic foodstuffs rather than a net importer relying on a constant supply of food from another country. Based on this description, national food self-sufficiency (NFS) could be defined as:

$N F S=E>I$

where $\mathrm{E}$ is exports and I is imports. National food security is achieved when exports outweigh imports of foodstuffs.

Although most net food exporting countries are food selfsufficient, food self-sufficiency does not automatically assure food security within a country (Clapp 2017). The two concepts are related but the traditional concept of food security does not distinguish whether the available, accessible, nutritious, and stable food is in fact imported or produced locally (Clapp 2014). However, food self-sufficiency effectively concentrates on the aspect of food supply making it a plausible indicator of the food availability component of food security.

This is important as the FAO classification of low-income food-deficit countries (LIFDC) is based on two criteria; namely whether imports of basic foodstuffs outweighs exports and whether the per capita gross national income (GNI) falls below the level used by the World Bank to determine eligibility for IDA assistance (FAO 2016b). The self-exclusion criterion can be applied if countries meeting the above criteria choose to be excluded from the LIFDC category.

\subsection{The global hunger index}

The Global Hunger Index (Fig. 3) tracks the state of hunger worldwide and highlights areas of the world where action to address hunger is most urgently needed. Approximately 124 million people suffer acute hunger with climate change and poor governance being identified as some of the major drivers of global hunger (von Grebmer et al. 2018). The scores for countries are based on the three dimensions of the GHI: inadequate food supply measured by undernourishment, child mortality measured by under-five mortality rate, and child undernutrition measured by wasting and stunting.

As shown in Fig. 3, Eastern Africa is experiencing serious and alarming levels of hunger thereby emphasising the need for urgent attention to food security issues and policy.

\section{National Dependence on fish}

Coastal communities are usually heavily reliant on marine resources with fish being a major contributor. The WWF (2016) link fish dependence to country-specific situations of 


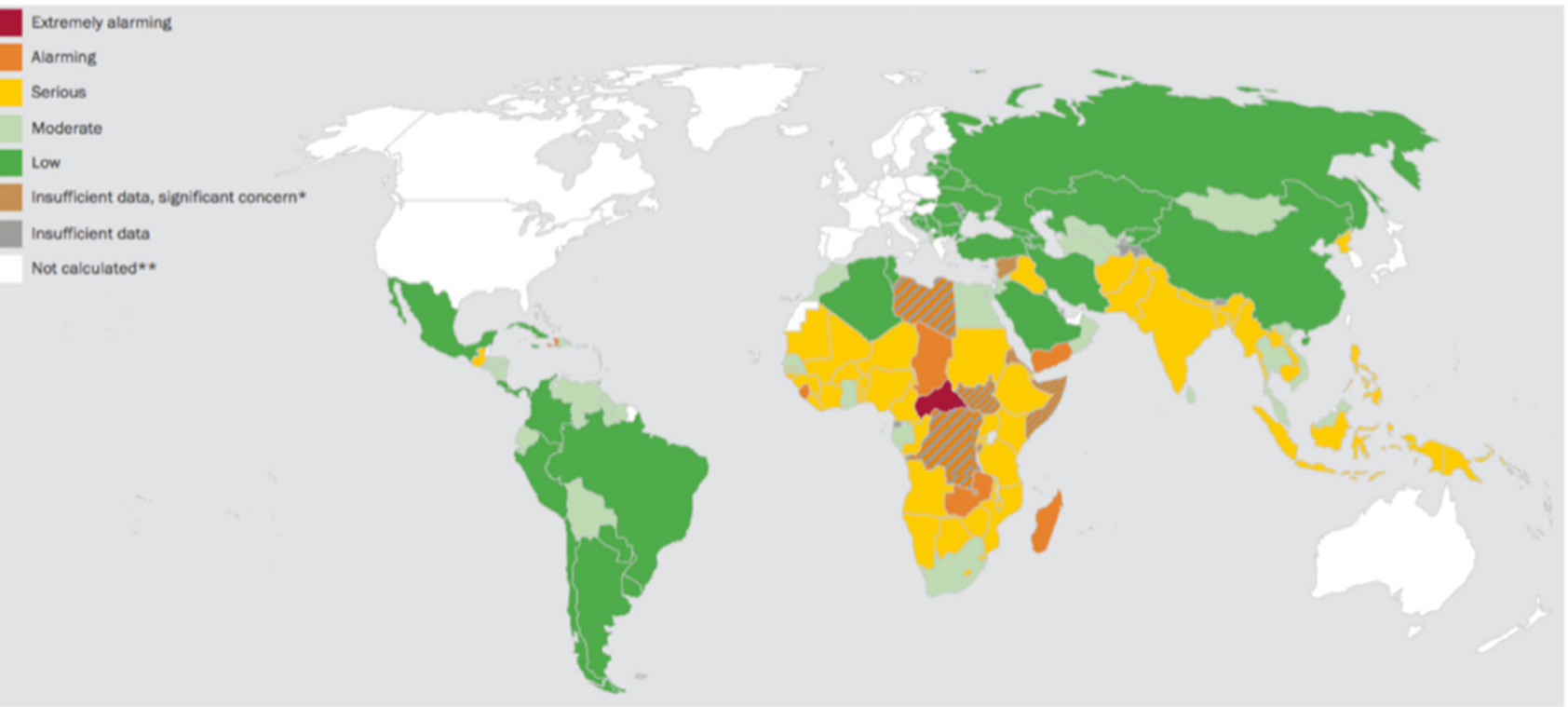

Fig. 32018 Global Hunger Index by Severity. Map in 2018 Global Hunger Index: Forced Migration and Hunger, by von Grebmer et al. (2018). Bonn and Dublin: Welthungerhilfe and Concern Worldwide

food security, fish consumption, capture production per capita, and the gross domestic product (GDP) per capita as a proxy for substitution capacity. Figure 4 taken from the WWF (2016) report shows the global result, which highlights Indonesia, Malaysia, Russia, China, Iceland, and most of Africa as heavily dependent on fish resources. The evaluation criterion includes measuring the amount of fish in a population's diet therefore functioning as an effective preliminary national assessment of dependence of the WIO country's on fish for food security.
The report also highlighted that fish production in the large marine ecosystems of the WIO countries are inadequately meeting current local demand, with catches of between 0.01-0.60 million tonnes only meeting between 0 and $80 \%$ of local demand (WWF 2016). The report concluded that poor countries with a large fishing sector run a very high risk of increased food insecurity if fish is lost as an income source.

Using the measures described above, Table 1 summarises the traditional global and national measurements used to quantify levels of food security, hunger, and fish dependence

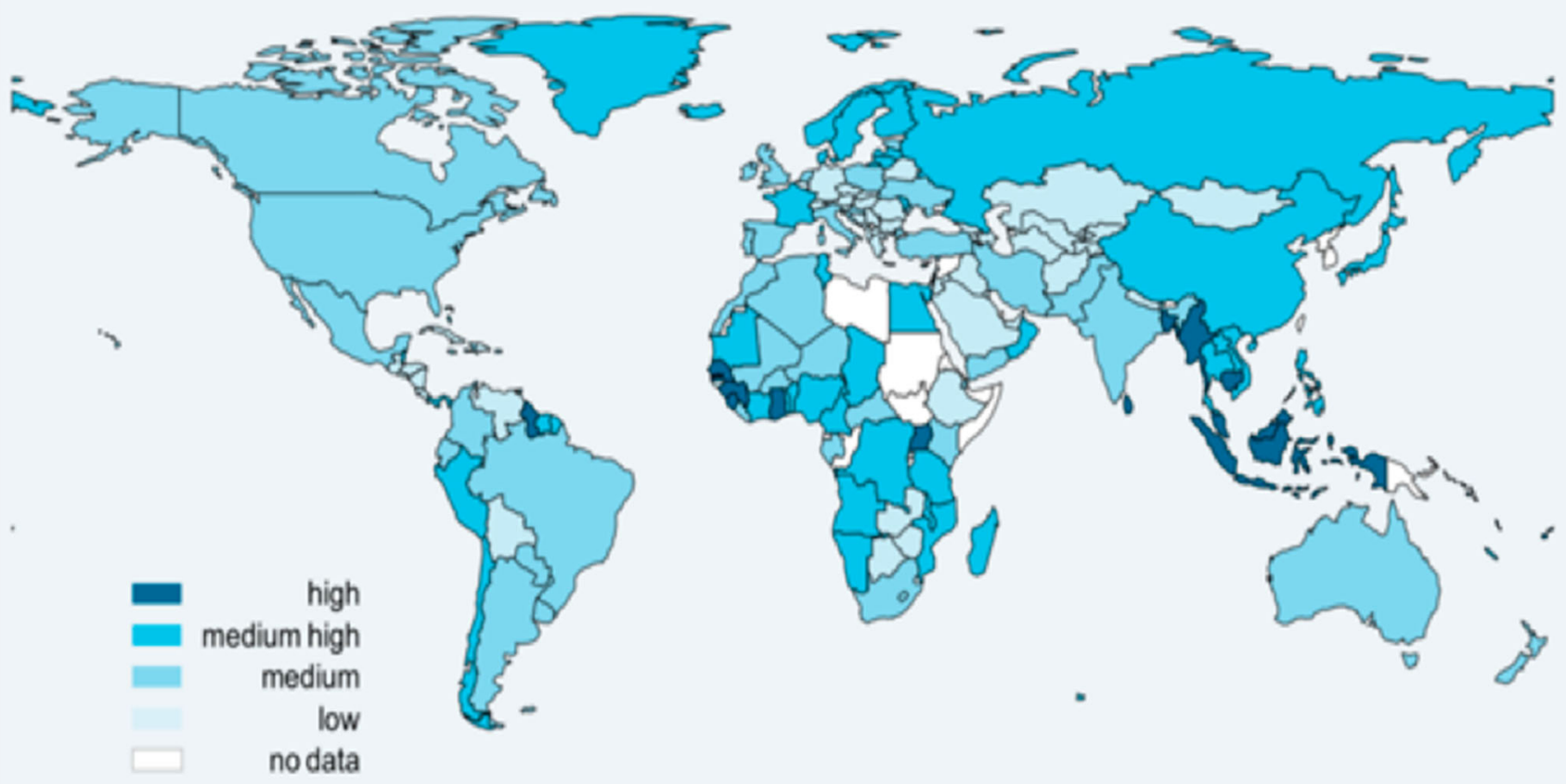

Fig. 4 WWF 2016 Overview of Global Fish Dependence. Fishing for Proteins. Note: includes freshwater fish 
specifically for the WIO countries. The values highlight that serious levels of hunger, undernourishment, and food insecurity are prevalent as well as a clear dependence on fish for protein and livelihood stability. The cells highlighted emphasise where the country is experiencing alarming results of each of the measurements. Kenya is one of the most alarming as there is high prevalence of severe food insecurity, high prevalence of undernourishment, imports of food outweigh exports suggesting that Kenya is not food self-sufficient on a national level, highly ranked on the GHI, and there is above average dependence on fish for food and protein. This is a sufficient national overview but what does this mean for the marginalised and isolated coastal communities within these countries when reduced ocean productivity puts further pressure on the WIO?

\section{6 "Marine" food security and the need to include coastal communities}

Small-scale fisheries form part of complex livelihoods embedded in local fishery economies that are crucial anchors for the social, economic, and cultural structure of isolated communities. They are vital for food security and are highly vulnerable to threats such as natural disasters and competition for largescale fishing (Allison and Ellis 2001; Jentoft and Eide 2011; World Bank et al. 2012). Fisheries are an integral part of ensuring food security worldwide with fish providing $6.7 \%$ of total protein consumed by humans (FAO 2016a). The fishery industry also provides direct and indirect employment for about 200 million people worldwide (McCord et al. 2011). Nine out of ten persons involved in capture fisheries are small-scale fishers, and are responsible for around half of the 60 million tonnes of marine fish caught for direct human consumption every year (UNEP 2005; Jaquet and Pauly 2008).
Small-scale fisheries therefore directly increase the availability of nourishing food for local, national, and international markets while also enabling people involved in the sector to receive a source of income (FAO 2015).

Even though small-scale fisheries prove to be economically and socially important, many small-scale fishing communities are still marginalised and their full potential and contribution to food security remains undervalued (Mills et al. 2011; Kolding et al. 2014). Food producing livelihoods, such as small-scale fisheries, have the potential to improve food security and levels of nourishment through direct consumption or indirectly through income (Fiorella et al. 2014). From a direct food security perspective, fish provides over 4.5 billion people with at least $15 \%$ of their average per capita intake of animal protein (Béné et al. 2015). Fish also contribute significantly to the income of over $10 \%$ of the world, therefore contributing indirectly to food security through livelihoods. Indirect food security may also include the economic benefits gained from exporting fish to international markets or the economic gains of fishing licenses purchased by international fleets operating in the EEZs of the WIO for example. In the case of countries of the WIO there is a need to further explore food security in coastal communities as small-scale fisheries provide a huge portion of the world with a supply of fish but are seemingly lacking adequate food security themselves (as shown in Table 1).

The role that fisheries, especially small-scale fisheries, play in ensuring food security in the WIO will be used as a proxy for the community scale of food security. Assessing the complex levels of dependency on fish in coastal communities will explore the food systems and potential levels of vulnerability to climate change induced food insecurity. The national scale of food security in the WIO will be assessed using adapted traditional methods of measurement such as national selfsufficiency on fish for food and the value fisheries add to WIO countries' Gross Domestic Product (GDP). This will
Table 1 Overview of WIO countries' level of food security, hunger, and fish dependence measurements

\begin{tabular}{ccllll}
\hline Country & $\begin{array}{l}\text { PoSFI in Total } \\
\text { Population }(2015- \\
\text { 2017) }\end{array}$ & $\begin{array}{l}\text { PoU in Total } \\
\text { Population }(2015- \\
2017)\end{array}$ & $\begin{array}{l}\text { LIFDC } \\
(2016)\end{array}$ & GHI (2018) & $\begin{array}{l}\text { WWF } \\
\text { Dependence on } \\
\text { Fish ( 2016) }\end{array}$ \\
\hline Comoros & $\%$ & $\ldots$ & & & \\
Kenya & 35.6 & 24.2 & Yes & Serious & Medium \\
Madagascar & $\ldots$ & 43.1 & Yes & Alarming & Medium high \\
Mauritius & 5.9 & 5.8 & No & Moderate & $\ldots$ \\
Mozambique & $\ldots$ & 30.5 & Yes & Serious & Medium high \\
Seychelles & 2.4 & $\ldots$ & No & $\ldots$ & $\ldots$ \\
Somalia & $\ldots$ & $\ldots$ & Yes & Lack of data, & No data \\
& $\ldots$ & & & significant & \\
South Africa & $\ldots$ & 6.1 & No & Moderate & Medium \\
Tanzania & $\ldots$ & 32.0 & Yes & Serious & Medium high \\
\hline
\end{tabular}


help conceptualise the economic dependence on fish. We therefore propose here a new view of looking at marine food security. We refer to this as the Marine Food Security Framework, which is a basic framework proposed as a preliminary assessment of the relationship between food security, coastal communities, small-scale fisheries, and environmental change.

The Marine Food Security Framework is demonstrated in Fig. 5 to illustrate the new definition of food security defined in this paper. Figure 5 addresses both the direct and indirect food security elements of marine food security within the context of fisheries in developing countries. We concentrate on three fisheries namely subsistence, artisanal, and formal fisheries. The subsistence fisheries do not partake in marketrelated activities and therefore are only related to direct marine food security. Direct marine food security is quantified by dependence on fish caught for food (diet dependence) shown as B in Fig. 5. This relates to food security on a household and community level. Artisanal fisheries contribute to direct food security, as fishers consume catch, and indirect food security, as catch can be sold to markets. This sector therefore lies between the two channels of marine food security and relates to food security on a household, community, and national level. The more formal fisheries sell catch to both domestic and international markets thereby contributing to national economic growth. Indirect food security relates to food security on a national economic level and is quantified by the value fisheries add to GDP shown as A in Fig. 5. Fisheries are only a percentage of a country's GDP, hence the fragmented illustration of GDP as a visual representation of economic growth. The three fishery sectors are not discrete as boats and fishers can operate in many sectors. However, the end product of the fishing activity in the sector is of importance to classify marine food security. The fisher catching fish to consume is direct marine food security while the fisher catching fish to sell to a domestic market for money is indirect marine food security as the sale has added to the economy and livelihood of the fisher.

With reference to Fig. 5, indirect marine food security relates to the importance of marine stock to national economies and livelihoods of the people involved in fisheries. This aspect of the model is important to analyse as the majority of people in the world have adequate access to food by having the necessary income to purchase food and not necessarily producing a sufficient diet entirely oneself (Staatz et al. 2009). Fisheries in this category of marine food security play a larger role in indirect food security as fishers participating in these formal fisheries, such as industrial large-scale fisheries, receive an income and don't necessarily fully rely on catch for direct food consumption security.

It is important to note here that the economic importance of fisheries is often underreported and undervalued (Misund et al. 2002; Mills et al. 2011). It has recently been proven that data for most important fisheries are underreported, especially in less regulated fisheries such as small-scale fisheries (Pauly and Zeller 2016). This results in misconceptions being drawn and the real value of fisheries to developing economies being undervalued.

Direct marine food security encompasses the true subsistence form of food security. Fisheries in this category are informal and often completely overlooked due to a lack of data. True subsistence fishers directly consume and share the fish caught with families and next of kin, rather than being bought by middlemen and sold at a larger market (WIOFish 2019). This group of fisheries and the fishers involved are therefore the most vulnerable to the declining productivity of the WIO as there potentially is no alternative livelihood available to stabilise levels of food security in these isolate coastal communities.
Fig. 5 Marine Food Security

Framework, where A is

Economic Dependence on

Marine Stock, and B is Diet

Dependence

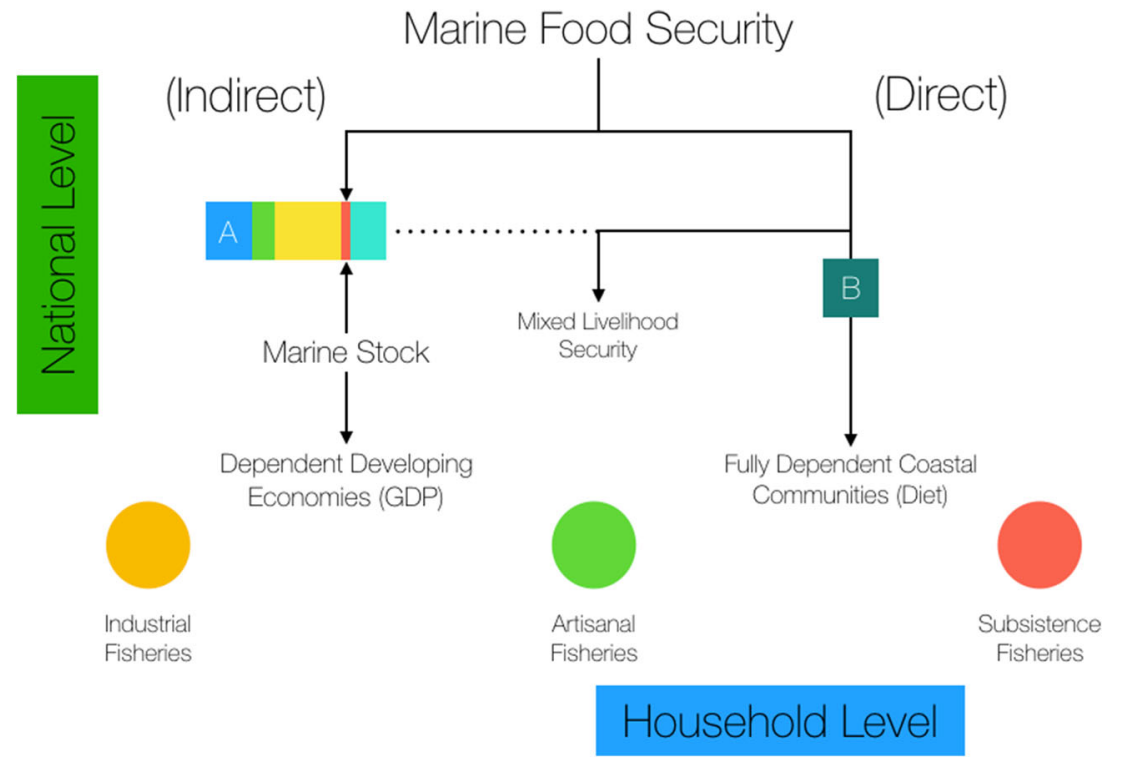


In addition to indirect and direct marine food security, it is important to note that there is an additional aspect namely Mixed Livelihood Security. This aspect of marine food security refers to fisheries, such as artisanal fisheries defined as fishing households using a relatively small amount of capital and energy with relatively small fishing vessels (if any) fishing close to shore mainly to sell catch to national domestic markets (WIOFish 2019). These fishers often eat a portion of their catch too, thereby substantiating the middle ground between direct and indirect food security. This access to food and an income for livelihood is why small-scale fisheries provide many communities with a source of food security and livelihoods (Béné et al. 2010; Jentoft and Eide 2011; FAO 2015). National data in many countries often only record primary occupation and may therefore misrepresent the nature of communities that rely on mixed livelihoods (Keskinen 2003).

The case of the WIO is highly relevant to use as a case study for assessing marine food security as the fisheries of the WIO vary from subsistence fisheries operating close to shore within EEZs right through to large industrial fleets fishing on high seas. For example, subsistence, artisanal, smallscale commercial, and semi-industrial fisheries operate within the purse seine fishery in Tanzania. Based on data collected from WIOFish (2019), this fishery provides direct food security as fishers are reported to eat a portion of their catch. The fishery operates in both territorial waters and the EEZ. The catch is also processed, whole frozen, and sold on in domestic markets thereby providing revenue and indirect marine food security to coastal communities. Similarly, the crab fishery in Kenya operates across all sectors providing direct food security to subsistence fishers and revenue to the artisanal and small-scale commercial sector selling catch in both domestic and export markets. There are also industrial sectors operating within EEZs, such as the tuna fishery in Comoros, which are foreign fleets that do not provide food security to the coastal communities and the catch is sold in foreign markets. Understanding the contribution to and impact on marine food security of these varying sectors will aid in understand the levels of dependence on marine resources for food security in the WIO.

\section{Results}

\subsection{National Fish Food Systems (indirect marine food security)}

The indirect marine food security (A in Fig. 5) status of the WIO dependent countries will now be assessed and quantified. The role of small-scale fisheries in developing economies is undeniable as $90 \%$ of small-scale fisheries are situated in developing countries (Hamilton 2018). They account for $38 \%$ of the total oceanic fish catch and are the ocean's largest employer, employing more than $90 \%$ of the world's capture fishers (FAO 2015). The issue lies in correctly quantifying the value of fisheries to a country's economic growth. Fisheriesrelated activities are typically reported at an aggregated level under "Agriculture, forestry, and fishing," therefore making it difficult to understand and quantify the economic value of fishing activities in isolation (de Graaf and Garibaldi 2014).

When disaggregated data are available, fisheries-related activities are commonly reported and grouped with aquaculture therefore still making fisheries GDP values not as informative as they could be to help policy makers and stakeholders realise the true value of fisheries to an economy. Small-scale fisheries are even more commonly overlooked and undervalued due to a lack of complete data and the complexity of the less regulated sectors (Mills et al. 2011).

FAO Food Balance Sheets are used to analyse a country's food system through three components namely domestic food supply, domestic food utilisation, and per capita values for the supply of the commodities. A food balance sheet primarily assessing fish and fishery products provides a comprehensive overview of the pattern of a country's fish supply. A food balance sheet of fish and fisheries has been constructed (Table 2) for the countries of the WIO, adapted from the FAO food balance sheets (2013) (FAO 2018c). The estimated coastal population has been added as an indicator of the size of the portion of population this paper is analysing. The WIO countries classified as LIFDCs are marked with asterisks.

The data from the fish food balance sheets are used to evaluate fish food trade and therefore levels of deficit or surplus. Assessing levels of food self-sufficiency gives indications to the trade and food security status of countries (Clapp 2017). Although food self-sufficiency does not automatically guarantee food security it will be used as a preliminary assessment tool to analyse fish food supply and trade. It should be noted that assessing trends of imports and exports of fish as food alongside levels of dependence on fish for protein might be an important indicator of changing oceans and fish distributions affecting food supply and therefore security more than defining an actual level of food security.

The measurement of the net food trade position of a country will be used as a proxy for the level of national fish food self-sufficiency (NFFS). Applying Eq. 4 to the marine food security framework, measuring national fish food selfsufficiency of a country can be calculated by assessing if exports of fish $\left(E_{F}\right)$ outweigh imports of fish $\left(I_{F}\right)$.

$N F F S=E_{F}>I_{F}$

Analysing the LIFDCs, the results of the national fish food self sufficiency correlate with the national food selfsufficiency results in the case of Comoros, Mozambique, and Somalia as these countries import fish (and food in 


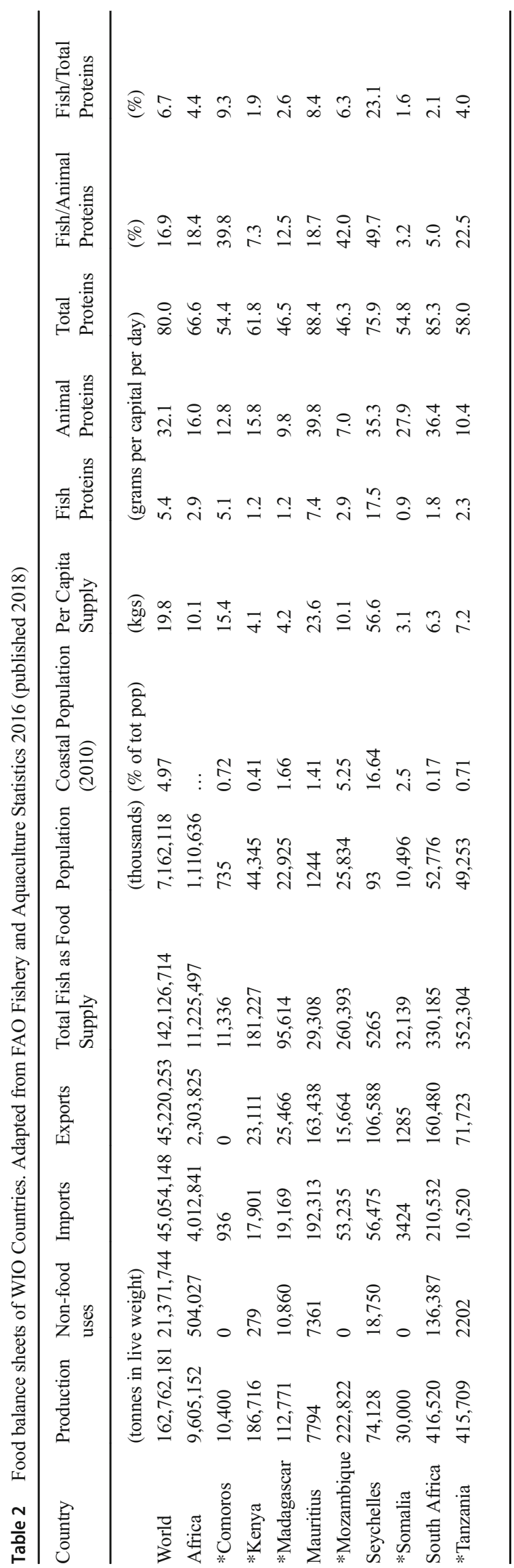

general) more than they export it. Interestingly Kenya, Madagascar, and Tanzania were found to be fish food selfsufficient and would therefore not be classified as food deficit countries in terms of fish and seafood.

South Africa and Mozambique prove to not be fish food self-sufficient even though on a general national scale they are classified as food self-sufficient. Seychelles is fish food selfsufficient, which correlates with the national food selfsufficiency status. This measurement could function as a primary overview of national marine food self-sufficiency as it exposes countries that are, on a national scale, unable to produce enough fish as food to meet all their demand if they are net importers.

The FAO food balance sheets measures per capita fish as food supply (PCFS) by calculating the total fish as food supply divided by the total population (PCFS). This is a reflection of how adequately countries are supplying the population with fish as a food source.

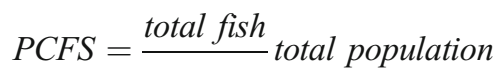

Kenya, Madagascar, Somalia, South Africa, and Tanzania have alarmingly low results that would suggest, based on this analysis and data, that these countries are possibly marine food insecure as their populations do not have sufficient access to adequate fish food supplies. In the case of Kenya this finding correlates with the results in Table 1 showing Kenya to be experiencing high levels of food insecurity, high prevalence of undernourishment, and serious levels of overall hunger. Madagascar and Tanzania are not adequately supplying their populations with fish which also correlates with Table 1 results showing alarming levels of undernourishment and hunger. South Africa appears to be at low risk of food insecurity on a national scale from results in Table 1. However, South Africa does not have sufficient access to adequate fish food supplies yet the country is quite dependent on fish according to the WWF results in Table 1.

As a preliminary assessment of individual dependence on fish for protein (DoF), the percentage of animal protein consumed by populations dependent on fish could be an indicator of direct marine food security on a national scale.

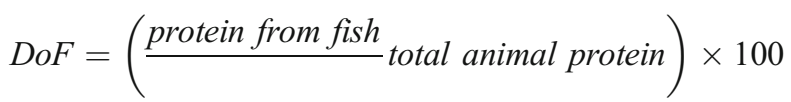

The DoF results found Seychelles and Mozambique to be the most reliant WIO countries on marine food security within this indicator analysis. The Comoros, Mauritius, and Tanzania are all highly dependent too as they ranked above the world average. These results correlate with the WWF results in Table 1 in the case of Mozambique and Tanzania. 


\subsubsection{Disaggregating fisheries data}

Fisheries data collected by the FAO suggest that global marine fisheries catch increased to 86 million tonnes in 1996 and then marginally declined. Pauly and Zeller (2016), using a decade long catch reconstruction project, identified noticeably different catch trajectories than those submitted to the FAO. The results suggested that catch peaked at 130 million tonnes, and has since been declining at a more rapid rate than previously assumed. This study proved a need to improve monitoring of all fisheries including the often-neglected small-scale fisheries.

As a secondary assessment of the value of fisheries in the WIO countries, data from the "Sea Around Us" was used to assess reconstructed catch and value of their fisheries (Table 3). The Sea Around Us assesses the impact of fisheries on the marine ecosystems of the world, offering comprehensive fisheries data through expert peer reviewed algorithms to reconstruct more accurate total catches as a solution to data poor countries and underreported data in fisheries. Thus, providing an estimation of unreported catch which is the portion of total catch in countries that is unregulated and not accurately reported for reasons such as a lack of capacity or regulation in smaller fisheries. The traditional aggregated measurement of the value added by agriculture, forestry, and fishing as a percentage of GDP is examined alongside disaggregated fisheries data of the specific fisheries sectors. By doing so, a more thorough analysis of the small-scale fisheries within each of the countries could be conducted to emphasise the oftenunderreported value and importance of small-scale fisheries to developing economies. All of the data is based on 2013 to maintain the same time frame as Table 2. Data on GDP and the value added totals of agriculture, forestry, and fishing industries were collected from the World Bank.

Total reconstructed catch and total reconstructed catch values were calculated using the equation:

$$
\text { TotCatch }_{s}=\sum_{s}(\text { Reported }+ \text { Unreported })
$$

where $\mathrm{s}$ is the fishery sector. For total reconstructed catch and catch values all fishery sectors were included in the sum. The subsistence, artisanal, and industrial sectors are separately evaluated as these fisheries form part of the marine food security framework and need to be analysed. Recreational fisheries were not included in this analysis as they fall outside of the marine food security framework. This formula was applied for total catch in tonnes and total catch value in real US\$ 2010 value.

\footnotetext{
${ }^{1}$ FAO acknowledged that catch reconstructions such as those done by the "Sea Around Us" help fill the gaps in national fisheries data and demonstrate how catches have really changed over time (FAO 2018b).
}

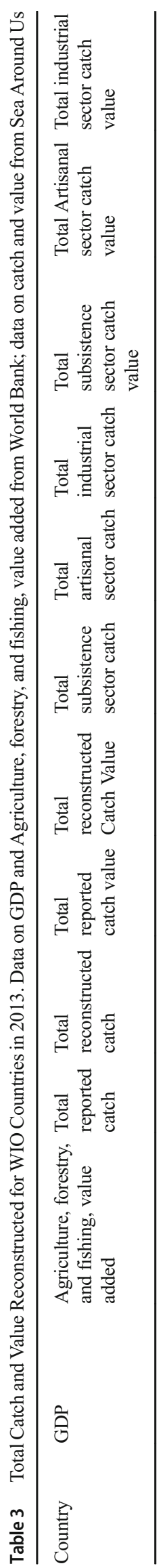

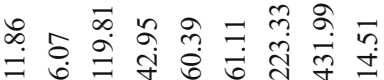

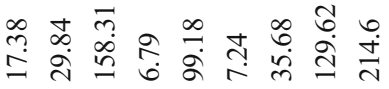

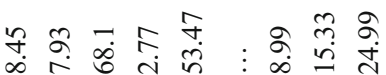

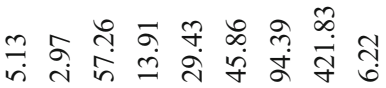

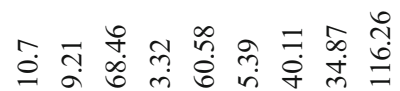

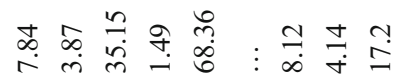

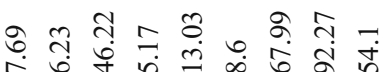

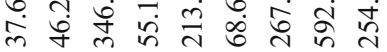

ڤิ山

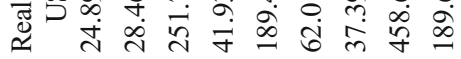

ळ

$\sigma$ గ

ஸे

Ұ

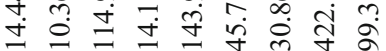

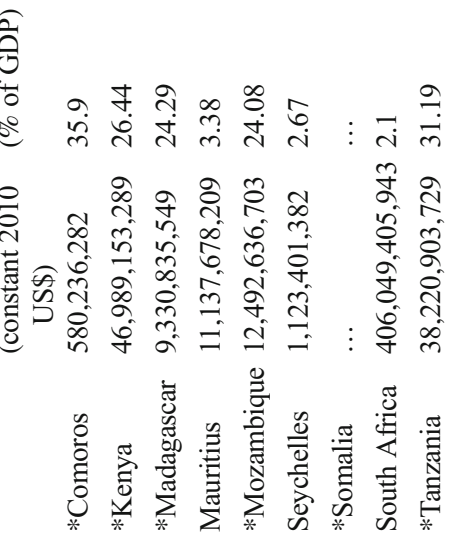


GDP is an important measurement of the size of an economy and can be used as a proxy for substitution capacity as in the WWF (2016) analysis of dependence on fish. Of the WIO countries South Africa has the largest GDP and Comoros has the smallest. Assessing the value fisheries add to the economic wealth of the WIO countries in Table 3 proved that the sector does not appear to contribute significantly to the GDP at the national scale except in the Comoros, which correlates with the results from McClanahan and Cinner's study on the region (McClanahan and Cinner 2012). However, in analysing South Africa it was interesting to note how underreported the values of fisheries were, by an estimated 133.63million US\$, which could attribute to the supposed low value fisheries add to the GDP. The results of disaggregating fisheries data also proved the value of smallscale fisheries outweigh the value of industrial sector in the Comoros, Kenya, Madagascar, Mozambique, and Tanzania.

South Africa has the largest total reconstructed catch therefore correlating with Table 2 proving South Africa to have produced the highest amount of fish. Somalia had the largest discrepancy between total reported catch and total reconstructed catch, with reported catch potentially underreporting the value of estimated actual total catch by 230.6 million US\$. Kenya is the least underreported with a difference of $7000 \mathrm{t}$ and catch value potentially being underreported by $17.77 \mathrm{mil}-$ lion US\$.

Disaggregating data on sectors helps identify the value of specific sectors to countries. The most important sectors to a country can be measured by looking at the sector with the largest catch and highest value of catch. In Mozambique this is the subsistence sector, Tanzania the artisanal sector, and South Africa's most important sector is the industrial sector.

An important result of Table 3 is to note that for the Comoros, Kenya, Madagascar, Mozambique, and Tanzania the value of the small-scale fisheries outweighs the value of the industrial sector. This proves the importance of disaggregating fisheries data in the pursuit of understanding the value of small-scale fisheries to economies.

\subsection{Coastal community food systems (direct marine food security)}

The direct marine food security (B in Fig. 5) status of the WIO dependent countries will now be assessed and quantified. Countries of the WIO have been identified as being dependent on fish for protein (direct marine food security) and as being dependent on fisheries economically (indirect marine food security). Specifically looking at the example of the Comoros and Mozambique where the population greatly depends on fish for protein and small-scale fisheries for economic stability and growth, an analysis of the marginalised coastal communities needs to be conducted to better understand the most vulnerable groups within the countries of the WIO. The data on the socio-economic side of the fisheries for the direct marine food security analysis are taken from "WIOFish" so to provide a more precise understanding and more reliable measurement on the habitual consumption of fish dependent coastal communities.

The importance of small-scale fisheries ensuring levels food security is further proven when analysing the severe reliance of fishers on fish for food. Table 4 illustrates the levels of marine food security from national dependence scaling down to the percentage of fisheries that contribute to food security on an individual and household level. A total of 266 fisheries in eight countries were analysed.

The criteria for the percentage of fisheries providing food security was whether the fishers are dependent on catch for food (even if it is just a portion of the catch). This satisfies the definition of direct marine food security as the fishers have access to fish as food. The criterion for the percentage of true subsistence dependence was the amount of subsistence fisheries within the fisheries defined as providing food security. This measurement emphasises the amount of truly dependent fishers who would be the most vulnerable to marine food insecurity, as they do not generate any income or derive livelihood from fishing activities.

Methodology and results from the dependency table pose possible measurements of direct marine food security (MFS) and direct true subsistence marine food security (TS). Using the percentage of fisheries providing food security as a proxy for marine food security in coastal communities and the percentage of subsistence fisheries as a proxy for direct marine food security the following calculations were developed:

$$
\begin{gathered}
M F S=\left(\frac{\text { FS fisheries }}{\text { total fisheries }}\right) \times 100 \\
T S=\left(\frac{\text { subsistence fisheries }}{\text { food security fisheries }) \times 100}\right.
\end{gathered}
$$

Where MFS is marine food security represented as the percentage of fisheries that provide fishers with food security. These fisheries are classified as FS (food security) fisheries if fishers within the fishery report that they eat all or a portion of their catch. Direct marine food security is measured as True Subsistence (TS), which represents the percentage of true subsistence fishers that rely on catch only for food. The fishers do not sell a portion of their catch, which makes their level of dependence on a healthy ocean the highest as they do not generate money from this activity, which would enable the fishers to purchase substitutes for fish if fish stocks were to decline.

\footnotetext{
${ }^{2}$ WIOFish is a collaborative programme originating out of identifying the dire need for more detailed information and understanding of small-scale fisheries that are extremely common in the WIO region. The data collected on the countries of the WIO (excluding Somalia) provides a better understanding of biological and socio-economic aspects of fisheries in the region.
} 
Table 4 Direct Marine Food Security Dependency Table. Data on seafood consumed and fish as a percentage of protein intake from World Bank, data on food security in fisheries from WIOFish

\begin{tabular}{|c|c|c|c|c|}
\hline Country & $\begin{array}{l}\text { Seafood } \\
\text { consumed } \\
\text { per capita } \\
\text { per year } \\
(\mathrm{kg})\end{array}$ & $\begin{array}{l}\text { Percentage } \\
\text { fish accounts } \\
\text { for in total } \\
\text { animal } \\
\text { protein intake } \\
(\%)\end{array}$ & $\begin{array}{l}\text { Percentage } \\
\text { of fisheries } \\
\text { providing } \\
\text { food } \\
\text { security } \\
(\%)\end{array}$ & $\begin{array}{l}\text { Percentage of } \\
\text { true subsistence } \\
\text { dependence } \\
\text { within food } \\
\text { security } \\
\text { fisheries }(\%)\end{array}$ \\
\hline Comoros & 15.4 & 39.8 & $46 \%$ & $73 \%$ \\
\hline Kenya & 4.1 & 7.3 & $77 \%$ & $58 \%$ \\
\hline Madagascar & 4.2 & 12.5 & $46 \%$ & $80 \%$ \\
\hline Mauritius & 23.6 & 18.7 & $81 \%$ & $12 \%$ \\
\hline Mozambique & 10.1 & 42.0 & $70 \%$ & $14 \%$ \\
\hline Seychelles & 56.6 & 49.7 & $81 \%$ & $17 \%$ \\
\hline South Africa & 6.3 & 5.0 & $53 \%$ & $42 \%$ \\
\hline Tanzania & 7.2 & 22.5 & $79 \%$ & $89 \%$ \\
\hline
\end{tabular}

Assessing the data collected from WIOFish most fishers in the WIO countries rely on a portion of their catch for their own food security. Out of the eight countries assessed in Table 4 only two, the Comoros and Madagascar, have a less than $50 \%$ share of fisheries providing food security. The significantly high percentages of fisheries providing food security to fishers and their families within the WIO region proves the high level of dependence on fish for food for these fishers and coastal communities.

Further analysing the fisheries providing food security in WIO region, the percentage of true subsistence fishers within those fisheries is significantly high in Tanzania, Madagascar, and the Comoros. Looking at Tanzania, the subsistence sector accounts for $89 \%$ of the fisheries that provide food security. Subsistence sectors in Madagascar and Comoros account for $80 \%$ and $73 \%$ respectively.

Countries with the lowest per capita seafood consumption interestingly prove to have a high reliance on fish and catch for food in their fisheries, such as Kenya, South Africa, and Tanzania. Cinner and Bodin's (2010) study also found a high community level of dependence on fish in contrast to nationallevel statistics for Kenya and Tanzania. This proves the importance of disaggregating data as on a national level it may appear that countries don't rely heavily on fish, but a high dependence is found when assessing coastal communities and fisheries. This shows the complexity of marine food security and why understanding local food systems will help address potential food insecurity in the future.

Seychelles proves to have the highest per capita consumption of seafood with one of the lowest percentages of fish as food dependent subsistence fisheries. This highlights the complexity of food systems and fish value chains in coastal communities as $81 \%$ of fisheries depend on fish for food but are mostly artisanal and industrial fisheries that will also sell portions of catch in domestic markets or receive an income from fishing activities too. Tanzania appears to have a low per capita consumption of seafood but a relatively high $22 \%$ dependence of protein on fish alongside a high $79 \%$ of fisheries providing food security. Results in Table 3 proved that Tanzania's most highly valued sector is the artisanal sector.

\section{Implications: So what does this mean for food security in the WIO?}

Our results of national and community-based scales of dependence are summarised in Table 5. This final table serves as an overview of national and community-based food security measurements used in this study to address the question of whether there is a potential food insecurity crisis. The shaded rows emphasise the most vulnerable countries. Comoros, Mauritius, Mozambique, and Somalia are the most vulnerable to food insecurity as they rank as the most alarming in each column of the food security measurements. Comoros, Mauritius, and Mozambique are reliant on fish imports, highly to extremely dependent on fish for protein at a national level and coastal community level, and highly to extremely dependent on fish for food within fisheries. These vulnerable countries are not fully aware of the real economic dependence on fisheries, as the values of their fisheries are all underreported. The case of Somalia highlights the danger of a lack of complete and accurate data. The value of their fisheries is underreported by an estimated $86.1 \%$, which triggers warnings of misunderstanding both the economic and social importance of fisheries within the country.

The levels of national dependence on fish for protein were ranked according to the world average (based on Table 2). Levels below the world average were ranked as low dependence, levels just above the world average were ranked as highly dependent, and levels that were prominently higher than the world average were ranked as extremely dependent.

The percentage of fisheries providing all or a portion of catch for direct consumption by fishers is used as a proxy for direct marine food security. The data used, from Table 4, classifies a fishery as providing food security if fishers eat all or a portion of their catch. Therefore, the percentage of fisheries providing food security was used to rank the level of dependence on fish for food. Percentages around 50\% were ranked as highly dependent and percentages above $70 \%$ were ranked as extremely dependent.

The results show a discrepancy between food security analyses at the national aggregated level using national statistics compared to more community based analyses using disaggregated fisheries data. In order for countries to fully understand how vulnerable they are to climate change affecting fish stock supply and food security, a 
Table 5 National and community scales of marine food security in the WIO

\begin{tabular}{lllll}
\hline Country & $\begin{array}{l}\text { National fish food } \\
\text { self-sufficiency }\end{array}$ & $\begin{array}{l}\text { Percentage of underreporting } \\
\text { the value of fisheries }\end{array}$ & National dependence on fish for protein & $\begin{array}{l}\text { Fisheries' Dependence on fish for } \\
\text { food }\end{array}$ \\
\hline NFFS $=E_{F}>I_{F}$ & Real 2010 value & DoF $=\left(\frac{\text { protein from fish }}{\text { total animal protein })} \begin{array}{c}\text { Percentage of fisheries providing } \\
\text { fish as food to fishers }\end{array}\right.$ \\
Comoros & Reliant on Imports & $33.9 \%$ & Extremely Dependent & Highly Dependent \\
Kenya & Self-Sufficient & $38.4 \%$ & Low Dependence & Extremely Dependent \\
Madagascar & Self-Sufficient & $27.3 \%$ & Low Dependence & Highly Dependent \\
Mauritius & Reliant on Imports & $24 \%$ & Highly Dependent & Extremely Dependent \\
Mozambique & Reliant on Imports & $11.1 \%$ & Extremely Dependent & Extremely Dependent \\
Seychelles & Self-Sufficient & $9.6 \%$ & Extremely Dependent & Extremely Dependent \\
Somalia & Reliant on Imports & $86.1 \%$ & Low Dependence & Highly Dependent \\
South Africa & Reliant on Imports & $22.6 \%$ & Low Dependence & Extremely Dependent \\
Tanzania & Self-Sufficient & $25.4 \%$ & Highly Dependent &
\end{tabular}

more granular approach such as the one used in this paper needs to be applied to understand the potential increase in food insecurity in the WIO.

With negotiations such as the IOTC allocating fishing opportunities for IOTC species, analysing both national and scaled-down food security assessments would be beneficial to more accurately understand the country's levels of dependence on the marine resources in question. This scenario shows the potential benefit of governments using national and disaggregated data to assess how a country would be impacted on both a national and community level when access to certain marine resources is limited locally or increased for distant water fishing nations. There may appear to be low dependence nationally on a marine resource thereby justifying access agreements with distant water fishing nations. However, smaller-scale fisheries and coastal communities may in fact rely heavily on that marine resource for food and livelihoods. Understanding the different levels of dependence and collecting both national and community level statistics would benefit ocean governance by countries being able to understand the trade-offs within such scenarios. The ESCAP and UN Environment led Ocean Accounts Platform is an example of a platform where all levels of data can be integrated to provide a more comprehensive view. The platform provides guidance on electing, prioritising, and standardising data of national, regional, and global importance (UN ESCAP 2018).

\section{Worrying trends?}

What of the future? If the indirect and direct dependence on a productive WIO continues what pressure will expanding populations, increasing SSTs, and fluctuating total catch place on marine food security?

Small-scale fishers are the oceans largest employer and, although often undervalued or realised, their contribution to food security and nutrition plays a large role in coastal communities (Allison and Ellis 2001). Global hunger is increasing, coastal populations are expanding, and increasing sea surface temperatures are affecting the productivity of ecosystems that many coastal communities in developing countries rely on. These important parameters are assessed to contextualise the potential impending food security crisis.

In the case of fisheries food security becomes a complex issue to solve as maintaining food security on a global level by supplying the increasing demand for seafood may lead to a decline in individual food security as small-scale fishers are fished out trying to compete with industrial fisheries. An everincreasing catch rate and habitat destruction above a sustainable threshold will result in increasing food insecurity for the small-scale fishers and the coastal communities that rely on their catch for food (CRS 2006).

Coastal areas are vulnerable as they are exposed to hazards such as sea-level rise and increasing SSTs (Fig. 6) that affect the already exposed small-scale fisheries. They are often more
Fig. 6 Time series of annual mean SST (degrees Celsius) over the Western Indian Ocean (WIO in red) and the Rest of the Indian Ocean (RIO in black). Source: Roxy et al. (2014)

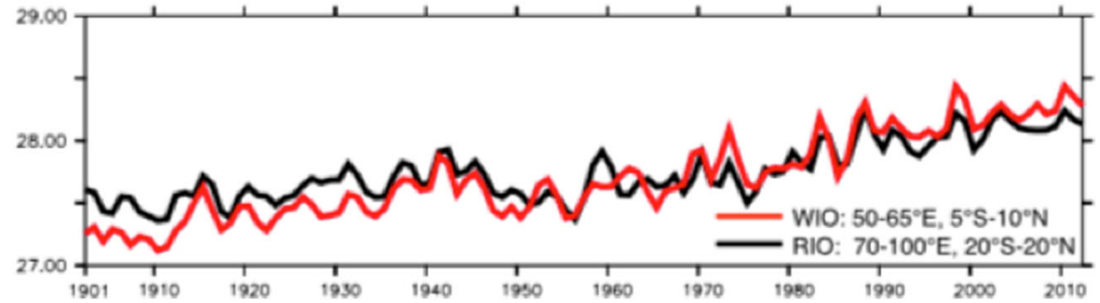


densely populated than inland areas and exhibit high rates of population growth and urbanisation (Neumann et al. 2015). Figure 7 illustrates the exponential increase in population size from 1993 to 2017 in the countries of the WIO.

Expanding populations increase demand for food (Boserup 2017). Global fish production is already approaching its sustainability threshold with approximately $90 \%$ of the world's stocks being fully or overfished (FAO 2016a). Overexploitation of fish stock has more than tripled since the 1970s and looking forward an estimated further a $17 \%$ increase in production by 2025 is anticipated (FAO 2016a).

The ongoing exhaustion of the world's marine fisheries is a worrying trend when considering the dependence on fish for direct and indirect marine food security in coastal communities. Overfishing proves to result in a loss of jobs, an increase in fish prices, and a reduction in income for coastal, regional, and national economies (Kellher and Webber Kelleher and Weber 2006). These impacts are particularly detrimental to developing countries where dependence levels on fish and levels of vulnerability are especially high such as the countries in the WIO.

Total catches and catch-per-unit-effort of fishing have radically declined over the past decades in many artisanal fisheries (Zeller et al. 2007; Bender et al. 2014; Muallil et al. 2014). Total catch is an important parameter as fishers and economies of the WIO rely directly on fish for food or indirectly through

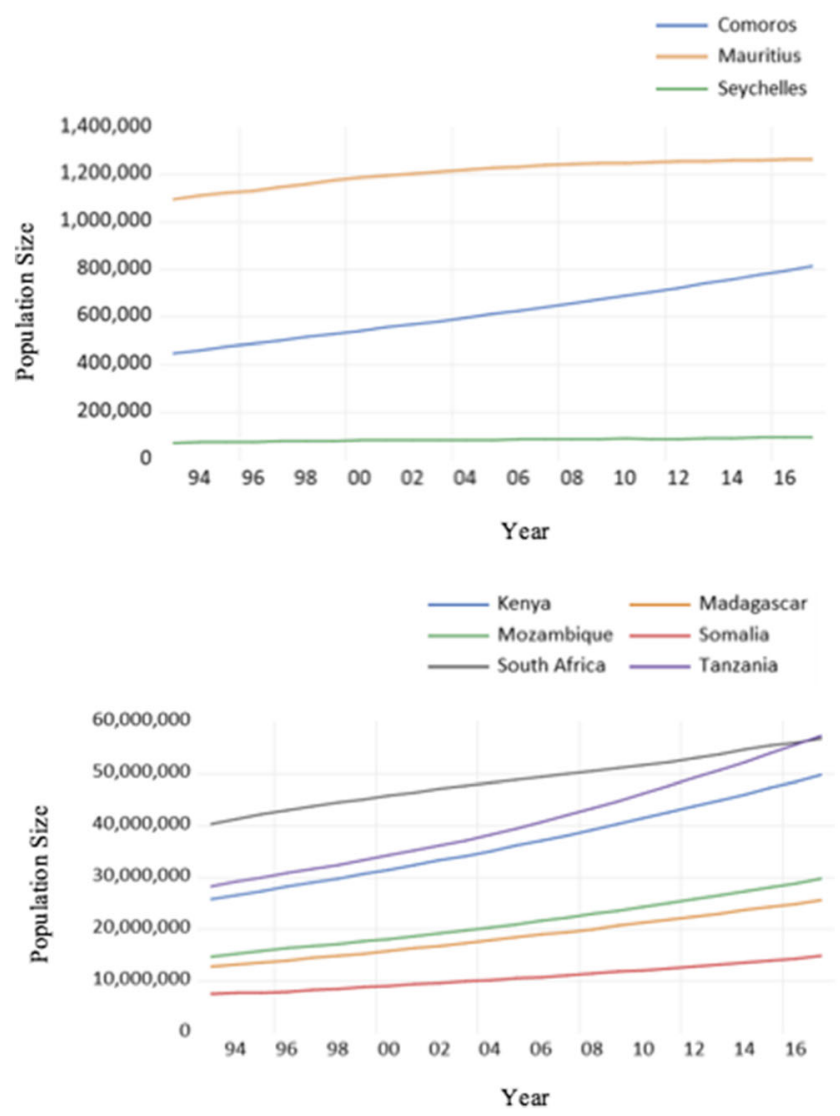

Fig. 7 Graphs of Expanding Populations. Data from World Bank livelihoods, income, and economic growth. Figure 8 illustrates the total catch (in tonnes) of the countries of the WIO from 1950 to 2014. The graphs are indicative of the portions of total catch accountable to the different sectors (subsistence, industrial, and artisanal) in the WIO countries. The black line on each of the graphs indicates reported catch over the years to show the difference between reported and the total reconstructed catch (Sea Around Us 2019).

A common trend is a noticeable peak in catch in the early 2000s in the Comoros, Mauritius, Seychelles, Somalia, and South Africa followed by a substantial steady decrease in catch since. Total catch in Tanzania also peaked in the early 2000s followed by a sharp decline that started recovering from 2008 onwards. There was, however, a decrease in catch between 2013 and 2014 and although catch seemed to be increasing it did not reach the peak catch of $154,210 \mathrm{t}$ in 2004. It is evident that smallscale fisheries are incredibly significant in Tanzania, as the artisanal sector accounts for majority of the total catch. In 2014 the artisanal sector accounted for $82 \%$ of the total catch.

Madagascar reached a peak catch of 187,110 t in 2009, with the artisanal sector accounting for largest portion of total catch. Total catch subsequently declined rapidly by $28 \%$ in 2014. In developing countries one of the main forces behind exploitation and declines in catch within small-scale fisheries is open access to fisheries, which results in over-capacity of fishing effort and fish stocks (Pomeroy 2011). Kenya and Mozambique seem to be the only countries experiencing an increase in catch, but in both cases have not recuperated levels back to their relative earlier peaks in catch.

\section{Conclusions}

The Marine Food Security Framework (Fig. 3) proposed in this paper is an attempt to illustrate the relationship between food security, coastal communities, and small-scale fisheries to contextualise the possible effects of a decrease in ocean productivity on highly dependent coastal communities. While the new methods we created to measure marine food security include traditional methods of quantifying levels of food security, we scaled the problem down to the coastal community level. Using small-scale fisheries providing fish for food as a proxy for food security, the countries of the WIO were found to be significantly reliant on fish for preventing food insecurity.

There are two weaknesses of this study that should be considered. The scale of the problem is based on the estimation that between 30 and 60 million people rely on the WIO coastal environment for goods, services, livelihood and income (UNEP-Nairobi Convention and WIOMSA 2015). We therefore do not have a completely accurate number to scale this problem on. The national measurements of food security (Food Balance Sheets) are a snapshot of the issue at a specific time period. Time series trends were not analysed to view the 

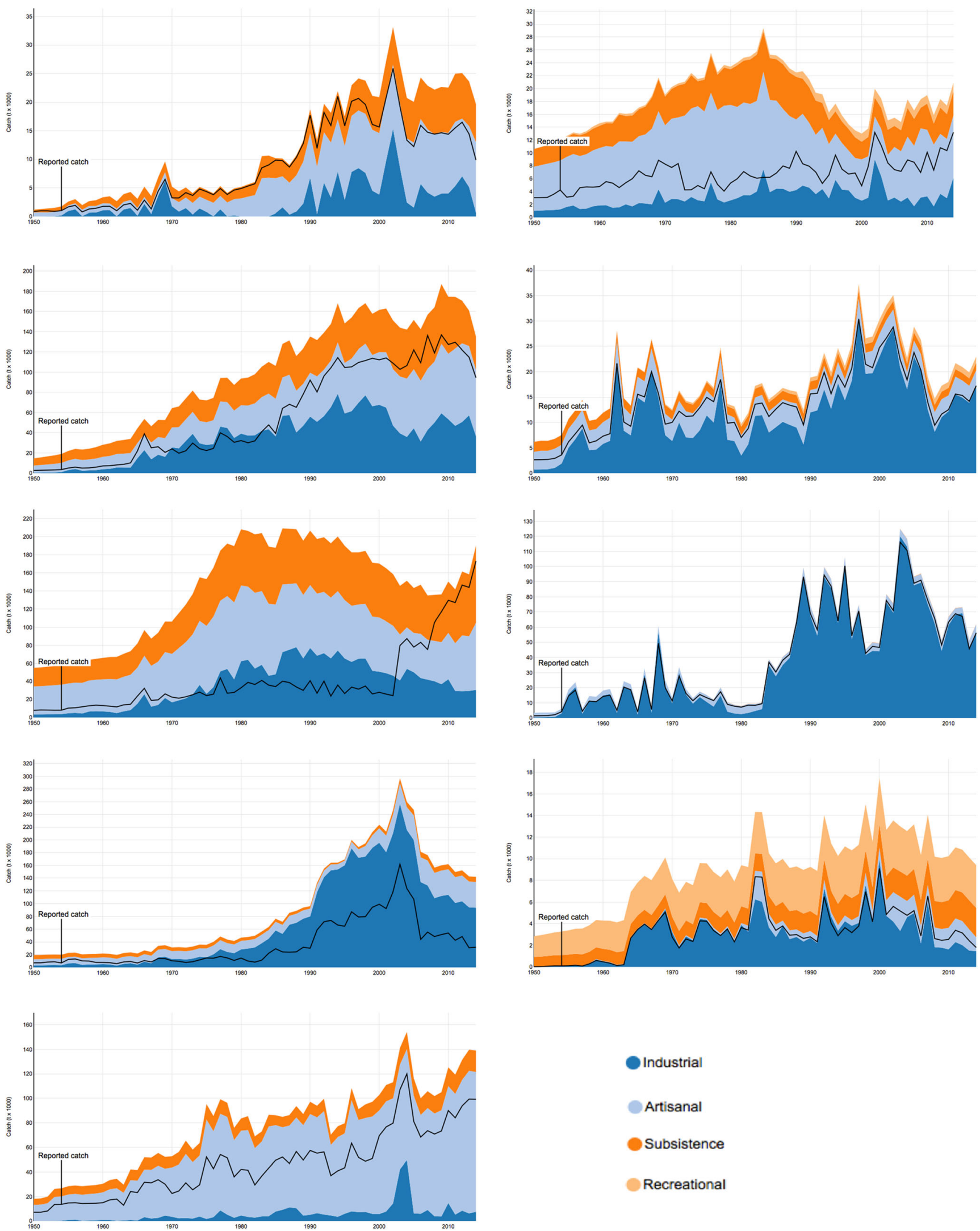

Fig. 8 Graphs of Catch by Sectors. Data and graphs generated from Sea Around Us (2018)

a) Comoros b) Kenya c) Madagascar d) Mauritius e) Mozambique f) Seychelles g) Somalia h) South Africa i) Tanzania 
overall trends due to the large sample size and qualitative nature of the paper.

The pivotal point of the food security issue in the WIO region is the misunderstanding that all individuals have equal access to adequate food supply when it appears that a country is food secure at a national level. The indirect marine food security analysis of national food security shows most countries as having sufficient supply of fish to be able to meet local demand and still export. This national overview does not, however, reflect the trends of food supply in coastal communities. The dependence of coastal communities on fish for food is larger than it seems, as subsistence fishers are not the only ones vulnerable to fluctuations in fish supply. The data shows that artisanal and industrial fishers also rely on fish for food and therefore direct food security, which makes the vulnerability of coastal communities larger than previously assumed.

An important lesson from this study is that food security analyses need to adopt similar scaled-down approaches to expose the weaknesses of single perspective food security studies. From the national perspective it appears that Kenya and Madagascar are marine food secure as they are selfsufficient and the national dependence on fish for protein appears to be low. Measuring marine food security on the community level challenges these national measurements, as fishers are extremely dependent on fish for food thereby relying on fish for household and individual food security. Relying solely on aggregated national data masks the looming potential food insecurity crisis in the WIO as worrying trends continue to add pressure on complex scenario.

We return to the key question of how big is the food security potential crisis? With an estimated 60 million people living within $100 \mathrm{~km}$ of the WIO shoreline the results illustrating significant household and national dependence on fish for food and economic health is worrying when acknowledging the increasing SSTs decreasing ocean productivity, expanding population pressurising food demand, and fluctuating total catch trends creating instability within small-scale fisheries. The Comoros, Mauritius, Mozambique, and Somalia appear to be the most vulnerable and will be extremely affected from both an indirect and direct food security perspective.

The overall message of this study is that WIO governments with highly populated coastal communities that are extremely reliant on the ocean for food and livelihoods need to relook at their national food security measurements and analyses. Marine food insecurity is looming in the face of a changing WIO all while aggregated data seemingly masks the severity of the problem at hand. Countries should consider applying this more granular approach to measuring food security. This study emphasises the need for countries to build structured datasets to enable more accurate calculation and monitoring of marine assets. By doing so governments will be able to better understand the severity of the potential marine food insecurity crisis in the WIO.

\section{Compliance with ethical standards}

Conflict of interest The authors declare that the research was conducted in the absence of any commercial or financial relationships that could be construed as a potential conflict of interest.

Open Access This article is distributed under the terms of the Creative Commons Attribution 4.0 International License (http:// creativecommons.org/licenses/by/4.0/), which permits unrestricted use, distribution, and reproduction in any medium, provided you give appropriate credit to the original author(s) and the source, provide a link to the Creative Commons license, and indicate if changes were made.

\section{References}

Allison, E. H. (2005). The fisheries sector, livelihoods and poverty reduction in eastern and southern Africa. In F. Ellis \& H. Ade Freeman (Eds.), Rural livelihoods and poverty reduction policies: Routledge studies in development economics (pp. 256-273). New York: Routledge.

Allison, E. H., \& Ellis, F. (2001). The livelihoods approach and management of small-scale fisheries. Marine Policy, 25(5), 377-388.

Applanaidu, S. H., Bakar, N. A. A., \& Baharudin, A. H. (2014). An econometric analysis of food security and related macroeconomic variables in Malaysia: A vector autoregressive approach (VAR). UMK Procedia, 1, 93-102.

Bell, J. D., Kronen, M., Vunisea, A., Nash, W. J., Keeble, G., Demmke, A., Pontifex, S., \& Andrefouet, S. (2009). Planning the use of fish for food security in the Pacific. Marine Policy, 33, 64-76.

Bender, M. G., Machado, G. R., De Azevedo Silva, P. J., Floeter, S. R., Monteiro-Netto, C., Luiz, O. J., \& Ferreira, C. (2014). Local ecological knowledge and scientific data reveal overexploitation by multigear artisanal fisheries in the Southwestern Atlantic. PLoS ONE, 9(10), e110332.

Béné, C. 2006. Small-scale fisheries: Assessing their contribution to rural livelihoods in developing countries. FAO fisheries circular. No. 1008. Rome, FAO. 2006. 46p.

Béné, C., Macfadyen, G. \& Allison, E. H. (2007). Increasing the contribution of small-scale fisheries to poverty alleviation and food security. Fisheries and aquaculture technical papers 481. Rome: Food and agriculture organization, 79.

Béné, C., Hersoug, B., \& Allison, E. H. (2010). "Not by rent alone": Analysing the pro- poor functions of small-scale fisheries in developing countries. Development Policy Review, 28, 325-358.

Béné, C., Barange, M., Subasinghe, R., Pinstrup-Andersen, P., Merino, G., Hemre, G., \& Williams, M. (2015). Feeding 9 billion by $2050-$ Putting fish back on the menu. Food Security, 7(2), 261-274.

Blasiak, R., Spijkers, J., Tokunaga, K., Pittman, J., Yagi, N. and Österblom, H. (2017). Climate change and marine fisheries: Least developed countries top global index of vulnerability. PLOS ONE, 12(6), p.e0179632.

Brink, S. (2001). Lack of food security. Hull, Quebec: Applied Research Branch.

Broca, S. (2002). Food insecurity, poverty and agriculture: A concept paper. Rome: Food and Agriculture Organization - Agriculture and Economic Development Analysis Division.

Cheng, L., Abraham, J., Hausfather, Z., \& Trenberth, K. E. (2019). How fast are the oceans warming? Science, 363(6423), 128-129.

Cinner, J. E., \& Bodin, Ö. (2010). Livelihood diversification in tropical coastal communities: A network-based approach to analyzing 'livelihood landscapes'. PLoS One, 5, e11999.

Clapp, J. (2014). Food security and food sovereignty: Time to get past the binary. Dialogues in Human Geography, 4(2), 206-211. 
Clapp, J. (2017). Food self-sufficiency: Making sense of it, and when it makes sense. Food Policy, 66, 88-96.

Coastal Communities Alliance (2015). Available online: https://www. coastalcommunities.co.uk [Accessed 1 August 2019].

Cochrane, L. (2017). Strengthening food security in rural Ethiopia. Okanagan: Doctorate of Philosphy. University of British Columbia.

CRS. (2006). Fisheries opportunities assessment. University of Rhode Island and Florida International University.

De Cock, N., D’Haese, M., Vink, N., van Rooyen, C. J., Staelens, L., Schönfeldt, H. C., \& D'Haese, L. (2013). Food security in rural areas of Limpopo province, South Africa. Food Security, 5, 269 282.

de Graaf, G. and Garibaldi, L. (2014). The value of African fisheries. FAO fisheries and aquaculture circular. No. 1093. Rome, FAO. 76.

FAO. (1979). Plan of Action on World Food Security, FAO Council Resolution, $1 / 75$.

FAO (1983). Director's General Report on World Food Security: A reappraisal of the concepts and approaches; Committee on Food Security, CFS. 83/4.

FAO. (1999a). Fisheries technical paper (No. 382) (113p). FAO: Rome.

FAO (1999b). Implications of economic policy for food security: a training manual. Available Online: http://www.fao.org/docrep/004/ x3936e/x3936e 03.htm [Accessed 20 December 2018].

FAO (2004). Advisory committee on fisheries research. Report of the second session of the working party on small-scale fisheries. Bangkok, Thailand, 10-21 November 2003.

FAO (2006). Policy brief: Food security. Issue 2. Available Online: http:// w w w. f a o. o r g/for e s t r y / 131328 0e6f36f27e0091055bec28ebe830f46b3.pdf [Accessed 16 March 2018].

FAO (2008). An introduction to the basic concepts of food security. Food Security Information for Action. Practical Guides. Available at: http://www.fao.org/docrep/013/a1936e/al936e00.pdf [Accessed 19 December 2019]

FAO. (2011). The state of food insecurity in the world 2010. Rome: FAO.

FAO. (2014). The state of world fisheries and aquaculture 2014. Rome: FAO.

FAO (2015). Small-scale fisheries. Available Online: http://www.fao.org/ 3/a-au832e.pdf [Accessed 9 November 2018].

FAO. (2016a). State of the World's fisheries and aquaculture. Rome: FAO.

FAO (2016b). Low-income food-deficit countries (LIFDC) - list for 2016. Available Online: http://www.fao.org/countryprofiles/lifdc/en/ [Accessed 12 March 2019].

FAO. (2018a). The state of food security and nutrition in the world 2018. Rome: FAO.

FAO. (2018b). The state of world fisheries and aquaculture (SOFIA) meeting the sustainable development goals. Rome: FAO.

FAO (2018c). FAO yearbook. Fishery and Aquaculture Statistics 2016. Rome: FAO. 104.

Fiorella, K. J., Hickey, M. D., Salmen, C. R., Nagata, J. M., Mattah, B., Magerenge, R., Cohen, C. R., Bukusi, E. A., Brashares, J. S., \& Fernald, L. H. (2014). Food Security, 6, 851-860.

Folland, C. K., Miller, C., Bader, D., Crowe, M., Jones, P., Plummer, N., Parker, D. E., Rogers, J., and Scholefield, P. (1999). Workshop on indices and indicators of climate extremes, Asheville, NC, USA, 3 6 June 1999: Breakout Group C: Temperature indices for climate extremes. Climatic Change, 42, 31-43.

Funk, C., Dettinger, M., Michaelsen, J., Verdin, J., Brown, M., Barlow, M., \& Hoell, A. (2008). Warming of the Indian Ocean threatens eastern and southern African food security but could be mitigated by agricultural development. Proceedings of the National Academy of Sciences, 105(32), 11081-11086.

Guerrero, B. J. E. (2010). Politics, globalization, and food crisis discourse. SSRN Electronic Journal.
Gustafson, D. J. (2013). Rising food costs \& global food security: Key issues \& relevance for India. The Indian Journal of Medical Research, 138(3), 398-410.

Hamilton, J. (2018). Supporting small-scale fisheries: World Bank aid, Objectives And Interventions Over Time. Masters. Nicholas School of the Environment of Duke University.

Heck, S., Béné, C., \& Reyes-Gaskin, R. (2007). Investing in African fisheries: Building links to the millennium development goals. Fish and Fisheries, 8, 211-226.

Houghton, J. T., Jenkins, G. J., Ephraums, J. J. (1990). Climate Change: the IPCC Scientific Assessment. Cambridge University Press, New York

Huanga, B., Thorne, P. W., Banzon, V. F., Boyer, T., Chepurin, G., Lawrimore, J. H., Menne, M. J., Smith, T. M., Vose, R. S., \& Zhang, H. (2017). Extended Reconstructed Sea surface temperature, version 5 (ERSSTv5): Upgrades, validations, and Intercomparisons. Journal of Climate, 30(20), 8179-8205.

IPCC. (2013). Climate Change 2013: The Physical Science Basis. Contribution of Working Group I to the Fifth Assessment Report of the Intergovernmental Panel on Climate Change. Cambridge University Press, Cambridge, United Kingdom and New York, NY, USA.

Jaquet, J., \& Pauly, D. (2008). Funding priorities: Big barriers to smallscale fisheries. Conservation and Policy, 22(4), 832-835.

Jentoft, S., \& Eide, A. (2011). Poverty mosaics: Realities and prospects in small-scale fisheries. Dordrecht: Springer Netherlands.

Kelleher, K., \& Weber, M. (2006). Toward sustainable Management of World Fisheries and Aquaculture. Washington D.C: World Bank.

Keskinen, M. (2003). Socio-economic survey of the Tonle Sap Lake, Cambodia. Masters: Helsinki University of Technology.

Kolding, J., Béné, C., \& Bavinck, M. (2014). Small-scale fisheries importance, vulnerability, and deficient knowledge. In M. Garcia, J. Rice, \& A. Charles (Eds.), Governance for marine fisheries and biodiversity conservation: Interaction and coevolution (pp. $317-$ 331). New Jersey: Wiley-Blackwell.

McClanahan, T. R., \& Cinner, J. E. (2012). Adapting to a changing environment: Confronting the consequences of climate change. New York: Oxford University Press.

McCord, M. and Zweig, T. (2011). Fisheries: Facts and Trends. South Africa. WWF, South Africa. 38.

Mills, D. J., Westlund, L., de Graaf, G., Kura, Y., Willman, R., and Kelleher, K. (2011). Under-reported and undervalued: Small-scale fisheries in the developing world. Pomeroy, R. S. and Andrew, N. L. Small-scale fisheries management: Frameworks and approaches for the developing world. Wallingford, Oxfordshire: CAB International, 1-15.

Misund, O.A., Kolding, J. and P. Fréon. (2002). Fish capture devices in industrial and artisanal fisheries and their influence on management. In: Hart, P. J. B. and Reynolds, J. D. (2) Handbook of Fish Biology and Fisheries. London: Blackwell Science, London. 13-36.

Muallil, R. N., Mamauag, S. S., Cababaro, J. T., Arceo, H. O., \& Aliño, P. M. (2014). Catch trends in Philippine small-scale fisheries over the last five decades: The fishers perspectives. Marine Policy, 47, 110 117.

Neumann, B., Vafeidis, A. T., Zimmermann, J., \& Nicholls, R. J. (2015). Future coastal population growth and exposure to sea-level rise and coastal flooding - a global assessment. PLoS One, 10(3), e0118571.

Obura, D., Burgener, V., Owen, S., \& Gonzales, A. (2017). Reviving the Western Indian Ocean economy: Actions for a sustainable future (p. 64). Gland: WWF.

OECD (2019). Available Online: http://www.oecd.org [Accessed 2 February 2019].

Pauly, D., \& Zeller, D. (2016). Catch reconstructions reveal that global marine fisheries catches are higher than reported and declining. Nature Communications, 7(1). 
Pomeroy, R. S. (2011). Managing overcapacity in small-scale fisheries. In: Pomeroy, R. and Andrew, N. L. Small-Scale Fisheries Management: Frameworks and Approaches for the Developing World. Wallingford, Oxfordshire: CAB International. 75-92.

Powledge, F. (2012). Food insecurity: An overview. In at issue: Food insecurity. New York: Greenhaven Press.

Rakotobe, T. (2012). Climate change in the Western Indian Ocean: A situation assessment and policy considerations. Africa Biodiversity Collaborative Group, 4245 North Fairfax Drive, Suite 100, Arlington, VA, 22203. Report October 2012. 118 pp.

Ravallion, M., \& Chen, S. (1997). What can new survey data tell Us about recent changes in distribution of poverty? The World Bank Economic Review, 11, 357-382.

Rice, J. C., \& Garicia, S. M. (2011). Fisheries, food security, climate change, and biodiversity: Characteristics of the sector and perspectives on emerging issues. ICES Journal of Marine Science, 68(6), $1343-1353$.

Roemer, M., and Gugerty, M.K. (1997). Does economic growth reduce poverty? CAER II discussion paper no. 5. Cambridge, MA: Harvard Institute for International Development.

Roxy, M. K., Ritika, K., Terray, P., \& Masson, S. (2014). The curious case of the Indian Ocean warming. Journal of Climate, American Meteorological Society, 27(22), 8501-8509.

Roxy, M. K., Ritika, K., Terray, P., Murtugudde, R., Ashok, K., \& Goswami, B. N. (2015). Drying of Indian subcontinent by rapid Indian Ocean warming and a weakening land-sea thermal gradient. Nature Communications, 6, 7423 .

Sea Around Us. 2018. Available Online: http://www.seaaroundus.org [Accessed 20 December 2018]

Sea Around Us (2019). Available Online: http://www.seaaroundus.org [Accessed 5 February 2019].

Sen, A. K. (1982). Poverty and famines: An essay on entitlement and deprivation. New York: Clarendon Press.

Singh, S. K. (2009). Nutritional and food security for rural poor through multi-commodity production from a lake of eastern Uttar Pradesh. Aquaculture Asia Magazine, 14, 23-25.

Smith, L., Khoa, S., \& Lorenzen, K. (2005). Livelihood functions of inland fisheries: Policy implications in developing countries. Water Policy, 7(4), 359-383.

Staatz J. M., Duncan H. Boughton, Cynthia Donovan. (2009). Food Security in Developing Countries. In: Phoenix, L. E. and Walter, L. Critical Food Issues: Problems and State-of-the-art Solutions Worldwide. Santa Barbra: ABC-CLIO, 157-176.

Teh, L. S. L., Lam, V. W. Y., Cheung, W. W. L., Miller, D., Teh, L. C. L., \& Sumaila, U. R. (2016). Impact of high seas closure on food security in low income fish dependent countries. PLoS One, 11(12), e0168529.

Thompson, P., Roos, N., Sultana, P., Thilsted, S. H. (2002) Changing significance of inland fisheries for livelihoods and nutrition in Bangladesh. In: Kataki, P. K., Babu, S. C. Food systems for improved human nutrition: linking agriculture, nutrition and productivity. Binghamton: Haworth Press. 249-317.

Timmer, P. C., Falcon, W. P., \& Pearson, S. R. (1983). Food policy analysis. Baltimore: Published for the World Bank by Johns Hopkins University Press.

UN ESCAP (2018). Asia and the Pacific regional expert workshop on ocean accounts. Available online: https://www.unescap.org/events/ asia-and-pacific-regional-expert-workshop-ocean-accounts [Accessed 5 January 2019].

UNEP (The United Nations Environment Programme). (2005). Artisanal fishing: Promoting Poverty Reduction and Community Development Through New WTO Rules on Fisheries Subsidies. An Issue and Options Paper. Available Online: https://unep.ch/etb/ events/pdf/AFSchoor.pdf. [Accessed 10 January 2019].
UNEP-Nairobi Convention and WIOMSA. (2015). The regional state of the coast report: Western Indian Ocean (546 pp). Nairobi: UNEP and WIOMSA.

Uraguchi, Zenebe. (2014). Payments for Marine Ecosystem Services and Food Security: Lessons from Income Transfer Programmes in Essam Yassin Mohammed (ed.) 2014. Economic Incentives for Marine and Coastal Conservation Prospects, Challenges and Policy Implications.

Van Wyk, R. B., \& Dlamini, C. S. (2018). The impact of food prices on the welfare of households in South Africa. South African Journal of Economic and Management Sciences, 21(1), 1979.

von Grebmer, K., Bernstein, J., Patterson, F., Sonntag, A., Klaus, L. M., Fahlbusch, J., Towey, O., Foley, C., Gitter, S., Ekstrom, K., \& Fritschel, H. (2018). Global hunger index: Forced migration and hunger. Bonn and Dublin: Welthungerhilfe and Concern Worldwide.

Wambogo, E. A., Ghattas, H., Leonard, K. L., \& Sahyoun, N. R. (2018). Validity of the food insecurity experience scale for use in subSaharan Africa and characteristics of food-insecure individuals. Current Developments in Nutrition, 2(9).

WIOFish (2019). Available Online: http://www.wiofish.org [Accessed 23 January 2019].

World Bank, FAO, and WorldFish Center. (2012). Hidden harvests: The global contribution of capture fisheries. Report no. 66469-GLB. Washington, DC: World Bank.

WWF. (2016). Fishing for proteins. In Hamburg: WWF Germany. International WWF: Centre for Marine Conservation.

Zeller, D., Booth, S., Davis, G., and Pauly, D. (2007). Re-estimation of small-scale fishery catches for U.S. flag-associated island areas in the western Pacific: the last 50 years. Fish Bull, 105, 266-277.

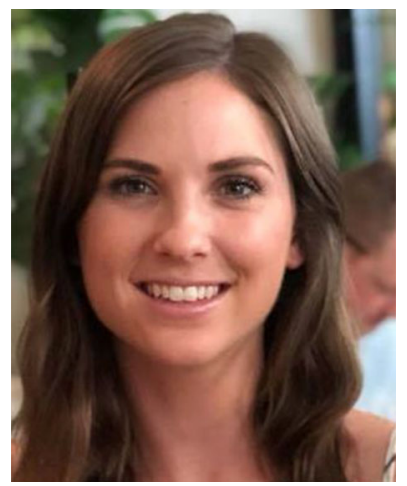

Sarah F. W. Taylor is an Environmental Socio-Economist at the National Oceanography Centre, UK. Her research line is focused around the field of food security in marine dependent countries, climate change, and the impact of changing oceans on developing economies, smallscale fisheries, and coastal communities. Her work within SOLSTICE-WIO, a four-year collaborative project funded by the UK Global Challenges Research Fund (GCRF), involves carrying out primary research in the field of marine food security and ensuring a link between scientific research and policy. 


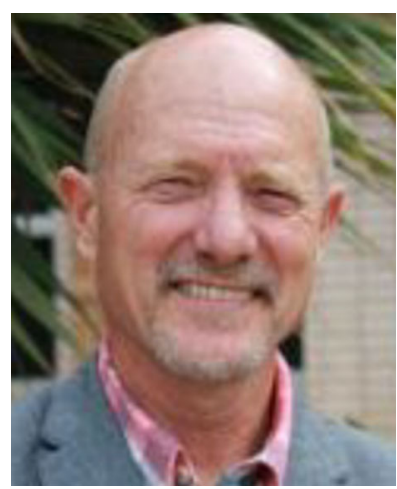

Michael J. Roberts is the UK-SA Bilateral Research Chair for Ocean Science and Marine Food Security. He holds a $\mathrm{PhD}$ in physical oceanography from the University of Cape Town. His current research investigates the underpinning processes that sustain food security (i.e. ecosystem functioning) with a strong focus on how climate change and a changing global ocean will impact marine upwelling systems in the western Indian Ocean. He has been chief scientist on more than 30 cruises and Principal Investigator (PI) of over 36 research projects ranging from national $\mathrm{NRF}$, fishing industry and government projects to large international projects including the ASCLME (Agulhas Somali Currents Large Marine Ecosystem), MESOBIO (Influence of mesoscale dynamics on biological productivity at multiple trophic levels in the Mozambique Channel), SAMOC (South Atlantic Meridional Overturning Circulation) and the Agulhas System Climate Array (ASCA).

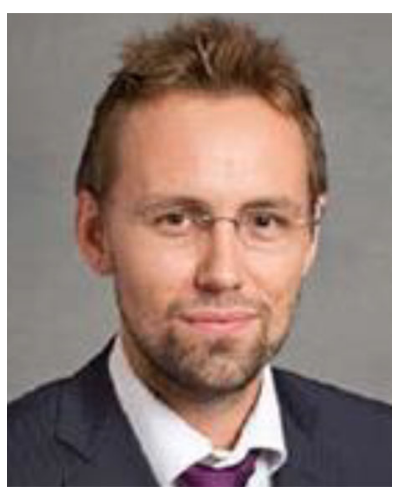

Ben Milligan holds a $\mathrm{PhD}$ in International Law from the University of Wollongong. He is a Visiting Senior Fellow at the Australian National Centre for Ocean Resources and Security, University of Wollongong, and has held Visiting positions at the British Institute of International and Comparative Law, George Washington University, University of Cape Town and University of Cambridge. His work focuses on environmental policy, marine and coastal resources management, and transnational environmental law. Particular interests include: management and regulation of ecosystem services; natural capital accounting; nature-based climate change mitigation and adaptation; and offshore infrastructure planning. Ben was the lead author of 2014 Global Legislators Organisation Study on Natural Capital Accounting. Hehas also provided consultancy services to clients including the PEW Charitable Trusts; Australian Government ministries; the Crown Estate Commissioners (UK); Commonwealth Secretariat; and African, Caribbean and Pacific Group of States.

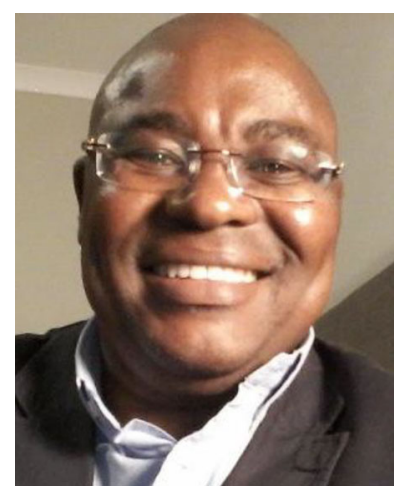

Prof Ncwadi is an Associate Professor and Head of Department of Economics at Nelson Mandela Metropolitan University in Port Elizabeth. He holds a PhD in economics from Nelson Mandela Metropolitan University (NMMU) and a certificate in Marine Studies from UPE /Washington University, USA. He has a finance background in a banking sector. Prof Ncwadi's areas of specialization are Public Finance, Money \& Banking, International Finance, Health Economics, Economics of Labour Markets, Macroeconomics, Development Economics and Econometrics. He is a member of international organizations, namely, Pan African Entrepreneurship Research Council based in the USA; Athens Institute for Education and Research (Greece) and also a member of BRICS Academic Forum (BRICS). 